NBER WORKING PAPER SERIES

\title{
IMPROVING EMPLOYMENT PROSPECTS FOR FORMER PRISON INMATES: CHALLENGES AND POLICY
}

\author{
Steven Raphael \\ Working Paper 15874 \\ http://www.nber.org/papers/w15874
NATIONAL BUREAU OF ECONOMIC RESEARCH
1050 Massachusetts Avenue
Cambridge, MA 02138
April 2010

This paper has benefited greatly from the input of Phil Cook, Jens Ludwig, Justin McCrary and Jeffrey Smith. The views expressed herein are those of the author and do not necessarily reflect the views of the National Bureau of Economic Research.

NBER working papers are circulated for discussion and comment purposes. They have not been peerreviewed or been subject to the review by the NBER Board of Directors that accompanies official NBER publications.

(C) 2010 by Steven Raphael. All rights reserved. Short sections of text, not to exceed two paragraphs, may be quoted without explicit permission provided that full credit, including $\odot$ notice, is given to the source. 
Improving Employment Prospects for Former Prison Inmates: Challenges and Policy

Steven Raphael

NBER Working Paper No. 15874

April 2010

JEL No. J15,J7

\begin{abstract}
$\underline{\text { ABSTRACT }}$
This paper analyzes the employment prospects of former prison inmates and reviews recent evaluations of reentry programs that either aim to improve employment among the formerly incarcerated or aim to reduce recidivism through treatment interventions centered on employment. I present an empirical portrait of the U.S. prison population and prison releases using nationally representative survey data. I characterize the personal traits of state and federal prison inmates, including their level of educational attainment and age as well as the health and mental health issues that occur with high frequency among this population. I then turn to the demand side of this particular segment of the U.S. labor market. Using a 2003 survey of California establishments, I characterize employers' preferences with regards to hiring convicted felons into non-managerial, non-professional jobs, the degree to which employers check criminal history records, and the incidence of legal prohibitions against hiring convicted felons. I conduct multivariate analyses of the impact of checking criminal backgrounds on the likelihood of hiring workers of difference race/gender combinations, using legal prohibition against hiring felons as an instrument for checking. Finally, I review the research evidence evaluating programmatic efforts to improve employment prospects and reduce recidivism among former prison inmates.
\end{abstract}

Steven Raphael

Goldman School of Public Policy

University of California, Berkeley

2607 Hearst Avenue

Berkeley, CA 94720-7320

stevenraphael@berkeley.edu 


\section{Introduction}

In 2007 over 725,000 inmates were released from either state or federal prison. Many of these individuals have served multiple terms in prison, cycling into and out of correctional institutions for much of their adult lives. Many have very low levels of education and little work experience, are disproportionately male and minority, and return to social networks with weak connections to the formal labor market. Not surprisingly, a high proportion of former inmates re-offends or violates the provisions of their conditional release, with the majority serving subsequent prison terms.

Stable employment is often characterized as being of central importance to the successful reentry of former inmates into non-institutionalized society. Most released inmates are in the age range when labor force attachment is the strongest and where conventional norms regarding responsible adult behavior center around steady work and support of dependents. Formal work may provide daily structure and routine that help keep former inmates from further run-ins with the law. Finally, steady employment (or the making of concerted efforts towards procuring steady employment) is often a provision of an inmate's conditional release, compliance with which is monitored by parole officers.

Former inmates face a number of challenges in searching for work. First, the relatively low human capital endowment of most former inmates limits their employment prospects. Second, stigma associated with felony convictions as well as outright employment bans further limits the available set of employment opportunities. Moreover, racial prejudice interacts in a complex manner with one's criminal history records in the screening and hiring practices of employers, further handicapping the employment prospects of prison releases. 
In this chapter, I analyze the employment prospects of former prison inmates and review recent programmatic evaluations of reentry programs that either aim to improve employment among the formerly incarcerated or aim to reduce recidivism through treatment interventions centered around employment. I begin by presenting an empirical portrait of the U.S. prison population. Using nationally representative survey data, I characterize the personal traits of state and federal prison inmates, including their level of educational attainment and age as well as the prevalence of physical and mental health problems. I then turn to those who are released in any given year. To be sure, releases differ from the stock of inmates at a particular point in time, in that those with shorter sentences are disproportionately represented. Nonetheless there is surprising consistency between the average characteristics of the stock and flow. Thus, the more detailed information available with regards to health, mental health, and substance abuse problems is likely revelatory with regard to those released from prison in any given year.

Having described the supply side, I turn to the demand side of this particular segment of the U.S. labor market. Using a 2003 survey of California establishments, I characterize employers' preferences with regards to hiring convicted felons into non-managerial, nonprofessional jobs. The data reveal a strong reluctance to hire such workers and the widespread use by employers of criminal background checks through for-profit security firms. In fact, the pervasiveness of the use of criminal background checks is such that it is unlikely that someone with a felony conviction can successfully conceal this information from employers. The employer responses also reveal that roughly one quarter of the employers of non-managerial workers are legally prohibited from hiring convicted felons. These employers are less likely to hire men, more likely to hire African-American applicants and less likely to hire Hispanics, especially Hispanic men. I conduct multivariate analyses of the impact of checking criminal 
backgrounds on the likelihood of hiring workers of difference race/gender combinations, using legal prohibition against hiring felons as an instrument for checking. The results for most groups are unstable across specification. However, the data strongly indicate that establishments that check are consistently more likely to hire African-American males, suggesting that the information revealed through background checks may be counteracting a high propensity among employers to assume all black applicants have criminal backgrounds.

With a solid characterization of the supply and demand sides of the labor market, I turn to a discussion of the research evidence evaluating efforts to improve employment prospects and reduce recidivism among former prison inmates. The volume of non-experimental studies of such efforts is great, and the central tendencies of the findings of this research tend to depart from the findings of experimental evaluations. While I present some discussion of meta-analyses of these non-experimental findings and discussion of why the conclusions from this research differ from the experimental analyses, I devote the bulk of my discussion to the handful of experimental evaluations that have occurred in the United States.

Characterizing the experimental research overall is difficult as the interventions are all quite distinct and the outcome variables analyzed differ considerably from program to program. Moreover, in the face of heterogeneity in the impact of such interventions and the availability of substitute programs for individuals randomized into the control group, it is difficult to decisively draw conclusions regarding the patchwork of efforts made across the country to aid the reintegration of former prison inmates. There is some evidence that providing transitional employment reduces recidivism among former prison inmates, with one particularly promising model being reproduced and evaluated experimentally at five locations across the country. There is conflicting evidence with regards to the impact of income support on criminal activity, with 
two separate experiments yielding conflicting results. These latter two studies illustrate the sensitivity of programmatic effects to contextual aspects of the intervention in terms of the manner in which support is delivered and the social services that are coupled with these efforts. There is also evidence that early interventions for at-risk youth that focus on basic education and workforce development appear to reduce arrest rates by significant and substantial amounts.

In general, the experimental research does provide reasons for optimism in that many of these efforts do yield significant impacts. However, the knowledge frontier regarding effective interventions is quite porous, as such experimental evaluations are few and far between. Given the large social costs associated with failed reentry, additional rigorous research on the effectiveness of such efforts is sorely needed.

\section{Characterizing prison inmates and prison releases}

Former inmates reentering non-institutionalized society face a number of challenges in procuring and maintaining stable employment. Of first order importance, former inmates tend to have low levels of educational attainment, little formal work experience, and have other characteristics associated with poor employment prospects. Those who serve time in U.S. prisons are hardly a random sample of the U.S. population. Individuals who pass through the nation's prisons tend to come from poverty, suffer disproportionately from physical and mental health problems as well as substance abuse problems, and come from minority groups with historically poor relative outcomes in the U.S. labor market.

Table 1 presents tabulations from the 2004 Survey of Inmates in State and Federal Corrections Facilities (SISFCF). The SISFCF is a nationally representative survey of prison inmates carried out by the U.S. Census Bureau. I use these data to describe the average 
characteristics of state and federal prisoners. While the majority of inmates are in one of the 50 state systems (90.4 percent), the federal prison system is quite large with the number of federal prisoners in $2007(199,000)$ exceeding the prison populations of the largest states (for example, California with 174,000 and Texas with 171,000). The table reveals several stark patterns. First, the prison population is overwhelmingly male (roughly 93 percent in both the state and federal systems), a pattern that describes U.S. prison populations throughout most of the twentieth century (Raphael and Stoll 2009). Educational attainment prior to prison admission is quite low. Among state prison inmates, fully two-thirds had less than a high school education prior to admission on the current prison term. The comparable figure for federal inmates is 56 percent. Racial and ethnic minorities are heavily over-represented among the incarcerated. Approximately one-fifth of state prison inmates are Hispanic as are one quarter of federal prisoners. Slightly less than half of both state and federal prisoners are African-American.

Prison inmates tend to be older than one might expect given the age trajectory of criminal offending. In particular, numerous researchers have demonstrated a sharp drop off in offending after 18 years of age, with greater proportions of those who are criminally active as youth desisting as a cohort ages through its twenties (Grogger 1998, Sampson and Laub 2003). Table 1 reveals that the median inmate is in his mid 30s, suggesting that for many prison is the lasting result of crime committed in one's earlier years. The SISFCF data do indeed reveal relatively early criminal initiation among those serving time. The median state inmate is arrested for the first time at the age of 17 while the comparable median for federal prison inmates is 18 . Moreover, when asked about when one commenced engaging in various criminal activities, the median inmate indicates 14 years of age. Fully 75 percent indicate that they were criminally active by age 16 . 
I am able to characterize the physical and mental health of prison inmates using the 2004 survey. The SISFCF asks whether one has ever been diagnosed with a series of physical and mental health conditions. It is difficult to assess whether prison inmates are more likely to suffer from the health conditions listed in the table, as the question inquires whether one has ever been diagnosed but does not measure the annual incidence or prevalence of the condition in question. Moreover, one would want to age-adjust in drawing comparisons to the general population. Nonetheless, there are some conditions for which the lifetime cumulative risk for inmates appears to be particularly high. For example, 9.5 percent of state inmates indicate that they have been diagnosed with hepatitis at some point in time. The combined annual incidence of hepatitis A, B, and C in 2006 among the U.S. population is approximately 3.1 per 100,000. ${ }^{1}$ Thus the lifetime risk for state inmates is over 3,000 times the annual incidence of the disease. For other conditions, such as diabetes for example, where ever being diagnosed is likely to be quite close to the prevalence rate, the proportion of inmates indicating that they are diabetic does not appear to be particularly high (4.7 percent of state inmates and 6.1 percent of federal inmates, compared with 11.2 percent for all U.S. men 20 or over).

It is perhaps easier to compare the prevalence of chronic mental health conditions to those of the adult population. For example, the inmate survey indicates that 9.7 percent of state inmates report that they have been diagnosed with manic depression, bipolar disorder. The comparable figure for all U.S. adults is roughly 2.6 percent. While 4.6 percent of state prison inmates and 1.9 percent of federal prison inmates indicate that they have been diagnosed with schizophrenia, the comparable figure for U.S. adults is 1.1 percent. $^{2}$ Prison inmates certainly

\footnotetext{
${ }^{1}$ http://www.cdc.gov/mmwr/preview/mmwrhtml/ss5702a1.htm accessed on November 8, 2009.

${ }^{2}$ http://www.nimh.nih.gov/health/publications/the-numbers-count-mental-disorders-in-america/index.shtml\#Bipolar Accessed on November 8, 2009.
} 
have high rates of current and prior substance abuse issues. Over 60 percent of both state and federal prison inmates indicate that they have participated in an alcohol/drug treatment program while incarcerated.

One might think that an incarceration spell would present an ideal opportunity to intervene and augment the job skills and educational attainment of prison inmates. As the tabulations at the bottom of Table 1 indicate, nearly 90 percent of inmates indicate that they will eventually be released from prison with well over half anticipating that they will be released within the next three years. When queried, however, few inmates indicate that they have participated in education or vocational training programming. For example, in state prisons only 27 percent indicate participation in a vocational/job training program, while 31 percent say they have participated in an education program. This low rate is consistent with the finding in WolfHarlow (2003) that only 26 percent of state inmates indicate that they complete a GED while incarcerated (equal to approximately 40 percent of inmates who had less than a GED upon admission). Participation rates in federal prisons are somewhat higher, though federal prisoners only constitute nine percent of the prison population.

To be sure, the reentry challenge in any given year is faced by those who leave prison and not necessarily the population of current inmates. In fact, for a sizable minority of the prison population, (at least 10 percent) release from prison is not a foreseeable possibility. Nonetheless, the characteristics of those released from prison do not differ appreciably from the average characteristics of the stock of inmates. Table 2 presents tabulations from the releases file of the 2003 National Corrections Reporting Program (NCRP) data. These data present micro-level information on all inmates leaving state prisons during the 2003 calendar year for participating states. In 2003, 35 states participated in the NCRP with the prison populations of the 
participating states accounting for 85 percent of the national total. I provide tabulations for all reentering inmates as well as inmates by race/ethnicity.

Similar to the stock of inmates, prison releases are overwhelmingly male (0.897) and are disproportionately minority (52 percent black and 20 percent Hispanic). Roughly 54 percent of returning inmates have not completed a high school degree, with a slightly higher figure for black and Hispanic releases and a slightly lower figure for white releases. The higher educational attainment among releases may reflect either positive selection along this dimensions or the completion of GED coursework while incarcerated.

The median reentering inmate is 32 years of age (two-years younger than the median prisoner) and is finishing a 21-month spell in prison. However, many of these inmates have served prior time, with fully 33 percent indicating that they have a prior felony incarceration (prior to the current spell). Certainly, many have also served time in local jails awaiting the adjudication of the charges leading to the current spell. These extensive histories inside correctional institutions are likely to further diminish the skills of former inmates relative to otherwise similar individuals who have not done time. In particular, cycling in and out of prison is likely to severely limit the accumulation of employment experience that is generally rewarded in the labor market. In prior longitudinal research on young offenders entering the California state prison system, I found that over a ten year period the median inmate of a given cohort of prisoners spends nearly six years cycling in and out prison (Raphael 2005). Finally, nearly threequarters of released inmates are conditionally released, meaning that they are under the active supervision of the state's community corrections system.

The observable human capital characteristics of prison releases can be used to characterize where in the earnings distribution these individuals are likely to fall. While there is 
no information in the NCRP regarding employment and earnings prior to incarceration, one can use data from the census to impute likely earnings based on observable characteristics and compare prison releases to all adult labor force participants.

To make this comparison, I first use data from the 2003 American Community Survey (ACS) to estimate the relationships between observable demographic and human capital characteristics and annual earnings. Specifically, using all adults 18 to 65 years of age with positive labor earnings during the course of 2003, I calculate average annual log earnings as well as the variance in log earnings by gender, age, race, and education level. ${ }^{3}$ I then assign annual earnings to each prisoner released in 2003 observed in the 2003 NCRP data using the earnings and variance estimate for each inmate's gender-age-race-education cell to draw an observation at random from the estimated distribution. ${ }^{4}$ Next, I estimate the vigintiles $\left(5^{\text {th }}, 10^{\text {th }}, 15^{\text {th }}\right.$ etc. percentiles) of the national annual log earnings distribution for all adults with positive earnings and for males only. I then calculate the cumulative distribution of prison releases across the vigintiles of each national distribution using the simulated earnings distribution for recent releases.

Figure 1 presents the results of this exercise. The simulated earnings distribution of inmates based on observable traits is heavily concentrated in the bottom of the national earnings distribution. Using the earnings distribution for all adults with positive income, approximately 46 percent of inmates are within the bottom quartile, while 70 percent lie below the median.

\footnotetext{
${ }^{3}$ For age, I define the brackets 18 to 20, 21 to 25, 26 to 30, 31 to 35, 36 to 40, 41 to 45, 46 to 50,51 to 55,56 to 60 , and 61 to 65 . For race I define the three categories white, black, and other. For education I define seven categories corresponding to the education groups defined in Table 2. Those who indicate special education are lumped into the category $8^{\text {th }}$ grade or less.

${ }^{4}$ I drop inmates that are less than 18 and over 65 years of age. This eliminates very few observations. In drawing random earnings observations I assume that the earnings distribution within cells is log-normal.
} 
Relative to the national earnings distribution for men, the simulation suggests that 56 percent of inmates lie within the bottom quartile while 75 percent have below median earnings.

Certainly, former prison inmates are likely to be negatively selected from the earnings distributions within these gender/race/age/education cells. Our description of the inmate population in Table 1 found a substantial prevalence of substance abuse and mental health problems and evidence that many of these men and women have been criminally active since very early ages. Such characteristics certainly would not increase labor productivity. Moreover, the tabulations from the NCRP data in Table 2 indicate that many of these inmates have served substantial amounts of time in prison. That is to say, within specific age cells, these inmates are likely to have less formal labor market experience relative to otherwise similar individuals who have not served time.

Thus the stock of current prison inmates as well as those released from prison in recent years are described by very low level of education, low levels of work experience conditional on age, high proportion minority, and a high prevalence of substance abuse, health, and mental health problems. Based on observable education, age, and race alone, it is likely that most of these individuals would be concentrated in the bottom quartile and the overwhelming majority below of the median of the nation annual wage and salary income distribution.

\section{The Demand Side of the Labor Market for Former Prisoners}

The characterization of former prison inmates strongly suggests that low human capital is one of their principal obstacles to securing and maintaining employment post release. ${ }^{5}$ Beyond

\footnotetext{
${ }^{5}$ One might contend that low human capital should not impact the likelihood that one is employed due to difficulty in securing a job. Specifically, wages should drop to clear the market for the least skilled workers, suggesting that wages should be lower for former inmates yet they should not suffer disproportionately from involuntary unemployment. Once we introduce search frictions however, the low human capital endowments of formers
} 
the impact of low skills endowments, there is reason to believe that employer hiring preferences and, in some instances, public policy may be further handicapping job seekers with criminal records. Employers may actively screen out those with prior convictions and prior time served for a number of reasons. First, employers may consider prior criminality a predictor of important unobservable traits, such as honesty or dependability. This may be particularly important to employers filling positions where monitoring by management is imperfect and where it may be difficult or costly to readily observe worker productivity.

Second, employers may fear being held liable for any criminal actions committed by their employees on the company's time. In negligent hiring/negligent retention cases, an employer may be sued for monetary damages caused by the criminal actions of any employee who the employer either knew or should have known had committed prior crimes rendering the employee unsuitable for the position in question. Not surprisingly, past research analyzing employer stated preference with regards to hiring those with criminal histories consistently finds that employers filling positions requiring substantial contact with customers are among the most reluctant to hire former prison inmates (Holzer, Raphael and Stoll 2006, 2007).

Finally, employers may be prohibited under local ordinances, state law, and sometimes federal law from hiring convicted felons into specific occupations. According to Bushway and Sweeten (2007), ex-felons are barred from employment in roughly 800 occupations across the country, with the composition of these bans varying across states and in some instance localities.

inmates as well as the stigma experienced in the formal labor market may lower the rate at which employment offers arrive. While endogeneous adjustment of one's reservation wage may offset the impact on unemployment duration, it is still likely that such less-desired job seekers will experience more unemployment as a result. Such reasoning is consistent with the strong empirical association between observable human capital and employment. It is also consistent with the noted large decrease in the exit rate from non-employment among black males that co-occurs with the notable declines in employment among black men (Juhn 1992). 
Occupations covered by such bans range from barber shop owners to emergency medical technicians to cosmetologists.

An additional factor that may further exacerbate the weak employment prospects of former inmates is the lack of regulatory guidance with regards to how and in what circumstances an employer should consider criminal history records. The Legal Action Center (2004) finds that in nearly all states there is no standard governing the consideration of prior criminal history records by employers and occupational licensing agencies. In many states, employers can fire anyone who is found to have a criminal history record regardless of the gravity of the offense, the time since conviction, or the relevance of the past behavior to one's current job responsibilities. In addition, employers are generally free to consider and discriminate based upon one's criminal history in hiring, with many states allowing employers to consider arrests not leading to conviction.

Whether reluctance among a subset of employers to hire former prison inmates or those with felony convictions results in market level impacts on employment rates, unemployment rates, and/or wages is an important question that parallels related theoretical and empirical debates in the economics of labor market discrimination. Specifically, discrimination against a specific group in the labor market by a subset of employers need not result in market-level wage differentials or greater difficulty in procuring employment. For example, the growing body of audit studies revealing lower call back rates for black workers (Turner et al 1991; Fix et al. 1993; Pager 2003) or workers with traditionally black names (Bertrand and Mullainathan 2004) certainly identify employers who exhibit bias in terms of their hiring choices. However, black workers may respond by concentrating their search efforts on firms with reputations for fair treatment, resulting in segregation across establishments. If black job searchers are a small 
group relative to availability of employment opportunities at firms that do not discriminate, the existence of discriminating firms will not lead to a racial wage disparity (Heckman and Siegelman 1993). ${ }^{6}$

In the current context however, the proportion of employers expressing reluctance to hire convicted felons is quite high (as we will soon see). Moreover, there are theoretical arguments based in the theory of search that indeed link the presence of employers that discriminate to market-level differences in employment and earnings through search frictions. Black (1995) presents a model whereby the existence of discriminating employers reduces the job-offer arrival rate experienced by black job searchers relative to white job searchers. Consequently, black job searchers lower their reservation wages and in equilibrium experience a wage penalty unrelated to productivity. The key aspect of this model is that even employers who do not bear animus against blacks workers have the incentive to offer black workers less, as they are more likely to accept the low wage offer.

In a recent working paper (Lanning 2010) has extended Black's model in several important directions and has developed a methodology for using search theory to simulate the impact of the differential call back rates on market outcomes. Lanning uses the reduced-form equations from a discrimination search model to estimate the reservation wages of youth in the National Longitudinal Survey of Youth 1979 (NSLY79). These reservation wage distributions are then used to simulate the impact of differences in hiring rates of an order of magnitude equal to those estimated in the extant auditing literature on unemployment duration and market wages by group. A key finding of this analysis is that modest differences in hiring rates can results in notable differences in outcomes between groups. As we will soon see, the stated reluctance to

\footnotetext{
${ }^{6}$ Heckman and Siegelman (1993) also argue that the matching on observables common in audit studies may not sufficiently account for difference in unobservable characteristics by group correlated with observable signals, or variance in these characteristics.
} 
hiring convicted felons is quite widespread. In the context of the models offered by Black and Lanning, such preferences may translate into wage penalties and lower employment for former inmates.

Interestingly, in a mid-1970s review of the employment problems of former inmates, Phil Cook (1975) reviews several studies that generally find little evidence that former inmates have great difficulty finding employment, although the jobs they found tended to be low-paying with little room for advancement. A dual labor market interpretation of these earlier studies would be that a criminal conviction and prison history do not impact the ability to find work, but may shut some former inmates out of the market for good jobs. However, this review was written at a time when the incarceration rate was roughly one-fifth today's rate and prior prison sentences may have been less salient as an issue to employers. Moreover, it is certainly more difficult to conceal a criminal history record today than in the past, a key factor cited in several of the papers reviewed in Cook (1975) explaining why a criminal record did not pose particular problems at the time.

How important is prior criminal history to the screening and hiring practices of employers? Can and do employers actually check the criminal pasts of their applicants? Does such screening impact the likelihood of hiring workers from specific demographic groups? In this section, I explore these questions using the 2003 Survey of California Establishments. The survey was conducted by the Survey Research Center at the University of California, Berkeley. The sample frame includes business and non-profit establishments with at least five employees excluding government agencies, public schools or universities, and establishments in either the agricultural, forestry, or fisheries industries. Establishments were first stratified by size group with each stratum sampled in proportion to the proportion of employment accounted for by the 
size category. Within strata, establishments are sampled at random. The intention behind the specific sampling frame is to generate estimates that are likely representative either for the average worker in these establishments or the average job seeker looking for employment in these establishments (assuming that hiring occurs in proportion to the stock of employees). A total of 2,806 establishments were sampled, 2,200 of which met the eligibility criteria (private sector, more than 5 employees). Interviews were completed with 1,080 establishments. ${ }^{7}$

\section{Descriptive analysis}

Table 3 presents tabulations regarding employer responses to queries about the acceptability of certain types of applicants for the most recently filled non-managerial, nonprofessional position. Employers are asked to think of the most recent position filled that meets these criteria. They are then asked whether they would definitely, probably, probably not, or definitely not accept a specific type of applicant. The survey inquires about three applicant traits: an applicant with a criminal record, an applicant who has been unemployed for a year or more, and an applicant with minimal work experience. ${ }^{8}$

Fully 71 percent of employers indicate that they would probably not or definitely not hire a worker with a criminal record (with definitely not being the modal response of 37 percent of establishments). The comparable figure for a worker who has been unemployed for a year is 38.6 percent while the comparable figure for a worker with minimal experience is 59.1 percent.

\footnotetext{
${ }^{7}$ The response rate for this survey (0.49) is roughly in line with comparable establishment surveys (see for example, Holzer 1995, Holzer, Raphael and Stoll 2006). The documentation for this survey does not provide detailed comparisons of the characteristics of responding and non-responding establishments, although it does note that the response rate was slightly lower for larger firms. The survey includes weights that adjust for differences in nonresponse rates across size categories as well as weights that adjust for differences in sampling rates across categories. The results presented in this section are not sensitive to whether one adjusts for differences in nonresponse rates across categories. All results presented here use the provided survey weights.

${ }^{8}$ The exact wording of the question is "Next, think about the most recently hired, non-managerial, non-professional position in your establishment. Please tell me if you would have definitely accepted, probably accepted, probably not accepted, or definitely not accepted each type for that position.” They are then queried about several type of applicants one of which is "... an applicant who had a criminal record." The survey does not specific whether this means someone convicted of felony, convicted of misdemeanor or an arrest record with no convictions (all of which may turn up in a background check).
} 
In prior research with Harry Holzer and Michael Stoll (Holzer, Raphael, and Stoll 2006) using data from an older establishment survey, we found a comparable reluctance to hire those with criminal records and much less reluctance to hire workers who have been unemployed, current welfare recipients, and workers with little experience. The one category of applicants for whom employers exhibit comparable (yet still less severe) reluctance to hire was applicants with gaps in their employment histories. Certainly, prior criminal history and unaccounted for gaps in one’s resume may be related in reality and in the minds of employers. In all, the California data and prior research clearly indicate a particular reluctance to hire workers with criminal pasts.

Whether and how employers act on the preferences evident in Table 3 will depend on the information they have regarding criminal histories. With direct information on criminal history records (either through a direct query of the applicant or through a formal information search), employers can screen directly on the information at hand. In the absence of such information, however, employers may use signals of prior criminality, such as race, gender, education, neighborhood of residence, or gaps in one's employment history, to probabilistically screen out workers with high likelihood (actual or perceived) of prior criminal activity.

Table 4 presents tabulations of employer responses to a question asking how frequently they check the criminal backgrounds of applicants for non-professional, non-managerial jobs. Nearly 60 percent of employers indicate that they always check criminal history records, while 12 percent indicate that they sometimes check. This figure is considerably higher than that observed in prior surveys. For example, in a mid-1990s survey of establishments in four metropolitan areas spread across the country, Holzer et. al. (2006) found that only 32 percent of employers indicated that they always check. A comparable 2001 survey of Los Angeles employers showed that roughly 46 percent of employers always check. While the differences in 
Table 4 relative to these earlier results may reflect the differing sample frames and locations, the higher propensity to check may reflect in part a decline in the cost of checking associated with increasing computer power, the computerization of criminal history records, and an increasing degree of openness of state criminal history repositories to public information requests.

Table 4 also presents these distributions by the employer's stated willingness to hire those with criminal histories and by whether the employer is legally prohibited from hiring a convicted felon into the job in question. There is a very strong relationship between checking and whether the employer indicates that a convicted felon is an acceptable applicant. While only 33 percent of employers who indicate that they would definitely accept a worker with a criminal history indicate that they always check criminal backgrounds, the comparable figure for those who would definitely not hire such a worker is roughly 70 percent. Regarding employers who are legally prohibited from hiring convicted felons (roughly 25 percent of the sample), 85 percent indicate they always check criminal backgrounds. The comparable figure for establishments not subject to such a legal prohibition is 52 percent.

Figure 2 presents tabulations of the methods used by employers to check criminal history records. Note, the proportions in the figure sum to more than one as employers can indicate that they use multiple methods to screen applicants on this dimension. A relatively small proportion of employers indicate that they simply ask the applicants (0.112), and an even smaller proportion indicates that they initiate their own query of the state Attorney General. Nearly 80 percent indicate that they outsource the screening to a security establishment such as Pinkerton.

Given the strong stated reluctance of many employers to hire convicted felons along with the apparent ubiquity of criminal history information, one might wonder which establishments are the most likely to hire former prison inmates and what impact, if any, do these preferences, 
legal prohibitions, and hiring practices have on employment outcomes. To explore these questions, Tables 5, 6, and 7 present the average characteristics of establishments after stratifying along a number of dimensions. Table 5 splits establishments into two groups: those unwilling to hire those with criminal history records (those indicating that they would definitely not or probably not accept such an applicant) and those that are willing (those indicating that they definitely would or probably would accept such an applicant). Table 6 stratifies employers into those legally prohibited from hiring a convicted felon into the mot recently-filled nonprofessional, non-managerial job and those that are not. Finally, Table 7 stratifies establishments into those that check criminal history records (either always or sometimes) and those that do not. In each table we present the industrial distribution, the distribution across size categories, the survey respondents perceived future hiring plans, and average characteristics of the recently hired non-exempt employee for each stratum.

Beginning with Table 5, there are a number of notable differences between establishments that are willing and unwilling to hire those with criminal history records. Construction and health services establishment are relatively overrepresented among establishments willing to hire. The latter finding is somewhat of a surprise, since health services establishments are often subject to bans on hiring convicted felons. Retail trade and other service establishments are somewhat underrepresented among those willing to hire. Unfortunately, the current survey does not contain information on the degree of customer contact that each employee will have. However, prior research using similar establishment surveys reveals a strong negative association between willingness to hire and the degree of contact between customers and the potential employee (Holzer, Raphael, and Stoll 2006). With regards 
to size, larger establishments are generally over-represented among employers who are unwilling to hire those with criminal history records.

Given the strong stated aversion to hiring applicants with criminal records, and the fact that this aversion is stronger than that observed for other applicants with problematic signals, one might hypothesize that an applicant with a criminal history record will be at the end of the hiring queue. In other words, employers may only hire such workers when unmet labor needs are great or during times of expansion. While I cannot assess how difference in labor market conditions impact employer attitudes towards such workers (the survey is of establishments in one state at roughly the same point in time), I can explore whether these attitudes depend on the employer's anticipated future hiring plans. Indeed, establishments that indicate that they plan to expand hiring are overrepresented among employers that are willing to hire applicants with criminal histories. The opposite is the case for establishments that indicate that they are planning to contract in the future. To the extent that this patterns holds up to controlling for other firm characteristics, this may provide guidance to labor market intermediaries serving former inmates regarding how to target the employment search.

Establishments that are willing to hire convicted felons tend to be filling positions with less educated people relative to establishments that are unwilling. Nearly 20 percent of recent hires at establishments that are willing have less than a high school degree, while roughly 70 percent have no more than a high school diploma. The comparable figures for establishments that are unwilling to hire is 2 percent and 37 percent, respectively. In addition, the establishments that are unwilling to hire pay considerably higher wages.

While there are no differences in the proportion female or the median age of recent employees at these establishments, establishments that indicate a willingness to hire applicants 
with criminal histories are more likely to hire black applicants, with a fairly large difference for black male applicants (3.2 percentage points). While at first one might expect that a strong aversion to hiring convicted felons should lower the probability of hiring black applicants, upon further reflection it becomes clear that the relationship between such preference and racial hiring outcomes is complex and may induce offsetting effects. Certainly, African-Americans, and African-American men in particular, are more likely to have criminal history records (Raphael 2005). As a consequences, one might expect that those employers that are the least willing to hire those with criminal histories should be the least likely to hire blacks. However, an aversion to hiring felons may interact with screening practices in a manner that might actually increase the likelihood of hiring a black applicant. Those who are unwilling to hire criminal applicants are also more likely to conduct formal criminal background reviews. If employers over-estimate the relationship between race and criminality, checking criminal backgrounds may actually improve the prospect of black applicants with clean histories. Holzer et al. (2006) find some evidence of such an impact, noting that those employers who are unwilling to hire yet don't check criminal backgrounds are the least likely to hire black applicants even after controlling for the relative supply of black applicants to the establishment.

There is additional research suggestive of the ambiguous impact of formal screening on the hiring of minority applicants. Autor and Scarborough (2008) find that formal screening devices do not reduce the hiring of blacks, despite the relatively poor performance of black applicants on standardized assessments. While this work does not address criminal background checks, the results parallel the argument made here. The authors analyze hiring outcomes at a large national retail chain that introduced formal test-based applicant assessment procedures. The relatively low black test scores coupled with the strong effect of scores on the likelihood of 
being hired yield the prediction that introducing the formal screening would reduce black hiring rates by nearly 20 percent. However, the authors find no such reduction, suggesting that the subjective assessments of black applicants by interviewers prior to testing negatively impacted black hiring rates.

While not directly addressed towards the issues of statistical discrimination, a recent audit study by Pager (2003) provides further evidence that employer perception of the relationship between race and criminality may interact in a complicated manner. Pager conducted an audit study in Milwaukee whereby pairs of auditors of the same race were sent to apply for the same jobs, one with a spell in prison listed on his resume and one with no such signal. Among the white auditors, 34 percent of the non-offenders received a call back in contrast to 17 percent of ex-offenders. The comparable figures for blacks were 14 and 5 percent. Consequently, Pager draws two conclusions. First, the ex-offender stigma effect is larger for black (based on the 65 percent reduction in the call back rates for black ex-offenders relative to the 50 percent reduction for whites). ${ }^{9}$ Second, that animus based racial discrimination against blacks is more important in explaining the inferior employment outcomes of black men (based on the finding that black non-offenders receive fewer call-backs than white ex-offenders).

However, statistical discrimination provides an alternative interpretation of the low call back rate for black non-offenders. In Pager's study, the auditor marked as an ex-offender explicitly signals having been in prison by including in-prison work experience on his resume. The non-offending auditor does not reveal a criminal past. If employers believe that all young black are criminally active, the low call back rate for black non-offenders may reflect statistical

\footnotetext{
${ }^{9}$ However, the percentage point decline in the call back rate for white offenders (17 points) exceeds the percentage point decline for black offenders (9 points).
} 
discrimination. ${ }^{10}$ Moreover, as noted by Bushway (2004), the audited sample of job openings explicitly excludes job openings where a background check is likely (for example, jobs that are legally closed to ex-offenders and job advertisements with explicit mentions of background checks). Moreover, the majority of employers audited care enough about the criminal backgrounds of the applicants to inquire about it on their application forms.

While employer apprehensions about hiring applicants with criminal histories are unlikely to aid the employment search of reentering former inmates, legal prohibitions against hiring felons most certainly close many doors. Nearly one quarter of the employers in the California survey indicate that they are legally prohibited from staffing their most recently filled exempt job with a convicted felon. Moreover, as the survey excludes public schools and universities, and government agencies, this may be a lower bound estimate of the proportion of recent hires bound by such prohibitions.

Table 6 presents comparisons of establishment characteristics for those indicating that they are legally prohibited from hiring a convicted felon into their most recently filled nonmanagerial, non-professional position and those indicating no such restriction. Beginning with industry, establishments in the financial services, insurance, and real estate, health services, and personal services industries are over-represented among establishments that cannot hire felons. To explore these patterns by industry in greater detail, appendix Table A1 presents the proportion of establishments that are subject to the legal prohibition by two-digit industry code. As the data becomes quite thin when spread across so many groups, the table also presents standard errors as well as the observation count for each industry. There are several notable

\footnotetext{
${ }^{10}$ One possible test of this hypothesis would be to assess whether there is an order effect on the likelihood that the black non-offender auditor received a call back. Specifically, in instances when the ex-offender applies first, the appearance of the prison information on the auditor's resume may prime a cognitive association between race and crime in the mind of the employer. To the extent that this triggers the subjective assessment of the employer, one should observe a lower call back rate for the non-offender black auditor in audits when he is the second to apply.
} 
patterns in these tabulations. We observe fairly high proportions of establishments subject to such legal prohibition in specific transportation, utility, and communications industries, including local passenger transportation. A similar pattern is observed for nearly all subcategories of the financial service industries. Over 35 percent of establishments in the health services industries are prohibited from hiring convicted felons, while 90 percent of social services establishments are subject to such prohibitions.

Returning to Table 6, there is little evidence of a systematic relationship between legal prohibitions and establishment size. Establishments that plan to expand in the future are somewhat underrepresented among those prohibited from hiring felons, however so are establishments that plan to contract. There are some notable differences in the average personal characteristics of recent hires. Establishments that are legally prohibited from hiring felons are more likely to hire women, more likely to hire African-American applicants, and less likely to hire Hispanics (Hispanic males in particular). The impact on gender may reflect the fact that convicted felons and released inmates are overwhelmingly male. The impact on the likelihood that the most recent hire is black is somewhat counterintuitive given the higher likelihood that African-Americans have criminal history records. However, statistical discrimination against blacks coupled with an impact of the prohibition on the likelihood that establishments check criminal history records may explain this pattern (we explore this issue in greater detail below).

Finally, establishments that are prohibited from hiring felons tend to hire more educated workers, with over 70 percent of recent hires having more than a high school degree. The comparable figure for establishments that are not prohibited is approximately 50 percent. Hourly wages at prohibited establishments exceed those at non-prohibited establishments by nearly 10 percent. 
The final comparison in Table 7 contrasts the characteristics of establishments that check criminal history records (either always or sometimes) in the process of screening job applicants to those that do not. As one might expect, establishments in industries where the proportion subject to legal hiring prohibitions is high are overrepresented among establishments that check (e.g. health services, other services, transportation, communications and utilities). Establishments that check are disproportionately larger, perhaps due in part to the fact that in these data larger establishments tend to be more likely to have formal human resource departments. There is no apparent relationship between whether an establishment checks and future hiring plans. We do, however, see a positive relationship between checking and proportion of recent hires that are female and that are black. Finally, establishments that check hire more educated workers and pay substantially higher wages (a nearly 20 percent wage difference).

The large wage premiums associated with checking criminal backgrounds, being unwilling to hire convicted felons, and being prohibited from hiring former prison inmates suggest that former inmates that do find jobs are overly concentrated in the very low-wage labor market (consistent with Cook's (1975) characterization of the labor market faced by formers inmates in the mid 1970s). These pay differentials may be interpreted as either reflecting productivity differentials between convicted felons and others (a traditional human capital interpretation) or perhaps convicted felons being relegated to low-wage secondary sector jobs (an interpretation more in line with dual labor market theory). Under the latter interpretation, acquiring secondary-sector employment may be less of a problem for former inmates relative to the problem of acquiring a job with decent pay and benefits. Indeed the patters evident in Tables 
5, 6, and 7 suggest that the employment opportunities available to convicted felons are generally inferior.

However, the recent audit evidence presented in Pager (2003) does show considerable penalties in terms of callback rates associated with a criminal history record. As was discussed in the review of the search models presented by Black (1995) and Lanning (2010), there are plausible and intuitively appealing theoretically arguments that link these lower call back rates to both more unemployment (as well as non-employment) and lower wages.

Multivariate Analysis

The descriptive statistics thus far reveal several patterns suggesting that employers consider criminal history records when screening job applicants and that such consideration may impact the demography of who employers hire. Moreover, the peculiar patterns regarding race suggest that the desire to screen out those with criminal histories may interact with employer perceptions of the likely past criminal behavior of applicants from different racial groups, and consequently impact hiring outcomes through a number of channels. In this section, I explore these patterns in greater detail. In particular, I assess whether the relationship between employer expansion plans and employer willingness to hire applicants with criminal histories survives controlling for observable establishment characteristics. I also model the impact of checking criminal history records on hiring outcomes using legal prohibitions against hiring felons as an instrument.

Table 8 presents the results from a series of linear probability regressions of a dummy variable indicating willingness to hire someone with a criminal history record (using the definition from the stratification in Table 5) on indicators for the establishment's future hiring plans as well as a host of control variables. The first specification only includes indicator 
variables for whether the establishment plans to stay the same size or contract in the near future (with planned expansion being the omitted category) as control variables. The second specification adds a complete set of dummy variables for the two-digit industry codes listed in Appendix Table 1A and seven size categories. Specification (3) adds a full set of interaction terms between the industry and size dummies, while specification (4) adds a dummy for being subject to prohibition against hiring felons, a dummy for whether the establishment checks criminal history records, and dummies for the educational attainment of the most recent hire.

Absent controls variables, there are indeed statistically significant differences in stated willingness to hire across establishments defined by their future hiring plans. Those who plan to stay the same size are roughly 7 percentage points less likely to indicate that they are willing to hire such workers relative to expanding establishments. For establishments that plan to contract, the comparable differential is 9 percentage points. The F-test of the joint significance of these two coefficients indicates that the difference in means across these three categories is statistically significant at the five percent level of confidence.

Adding industry and size dummies to the specification does not appreciably alter this result although the addition of these two sets of control variables attenuates the coefficients slightly. Permitting interaction terms between industry and size category, however, yields insignificant coefficients on the variables measuring future hiring plans in both specifications (3) and (4). This is in part due to the relatively large standard errors in these more complete specifications (relative to effect sizes estimated in model (1) with no controls). Thus, while there is some support for the hypothesis that expanding establishments are more likely to hire convicted felons, this result is somewhat sensitive to controlling for observable characteristics. 
A legal prohibition against hiring convicted felons can impact hiring outcomes through two channels. First, through reviews of criminal history records or through deterring applications from job seekers with felony convictions, such a prohibition will directly exclude convicted felons from employment, a factor that will disproportionately impact demographic groups with high felony conviction rates. Second, the additional screening prompted by the legal prohibition may counteract erroneous subjective beliefs, revealing clean criminal histories where employers might assume otherwise. Such a salutary effect should also have a disproportionate impact on the hiring of applicants of groups with high felony conviction rates, as these are perhaps the applicants that employers are more likely to assume have criminal records.

Table 9 presents results from a series of multivariate regressions of specific hiring outcomes on a dummy variable indicating that the establishment was legally prohibited from hiring a convicted felon into the most recently filled position. As all of the dependent variables analyzed are binary, all models are linear probability models. The table presents only the coefficient on the prohibition dummy to conserve space. Specification (1) includes only the prohibition dummy. Specification (2) adds a complete set of two-digit industry and size dummies, while specification (3) adds interaction terms between industry and size.

The negative impact of prohibitions on the hiring of male applicants disappears after adding controls for industry and establishment size as do the initially significant effects for black women and Hispanic men. For Hispanics overall and Hispanic women, the specifications beyond the bivaraite model in column (1) show significant negative impacts of the prohibition.

For black males, the table reveals a consistently significant (at the one percent level of confidence) positive impact of felony prohibitions on their likelihood of being hired. The probability that the most recent hire is a black male increases from three to 6.8 percentage points 
(depending on the specification) when the establishment is prohibited from hiring felons. To be sure, it may be the case that jobs that are legally off-limits to convicted felons draw disproportionately from the pool of African-American male workers. Unfortunately, the data do not include any variable gauging the racial composition of the applicant pool, although one might believe that black job applicants would also be drawn towards firms where they feel the likelihood of being treated fairly is high. It is notable that we do not see a positive significant effect of the prohibition on the likelihood that black women are hired beyond the estimate from the bivaraite specification in the first column.

Finally, Table 10 presents the instrumental variables models relating checking to hiring outcomes. For each model, the prohibition against hiring felons is used as an instrument for whether or not the establishment checks criminal backgrounds. The identifying assumption here is that the prohibition impacts hiring outcomes only through an impact on the use of this particular screening tool. This assumption would be violated if past problems with felon employees usher in the hiring prohibitions and if the incidence of such problems is correlated with the gender and/or racial composition of workers at the firm. The first stage coefficient on the legal prohibition dummy is presented in the last row of the table. The instrument exhibits a strong and significant impact on the likelihood of checking in all specifications.

There is little evidence of an impact of checking that is consistently significant and stable across specifications for males overall, for black females, and for Hispanic males. We do observe a consistent positive effect of checking backgrounds on the likelihood that the most recent hire is an African-American male. While the standard errors are quite large on these estimates, the estimates are significant at the one percent level in all specifications. To be sure, these local average treatment effect estimates are likely too large to represent what would happen 
on average if all employers were subjected to such a restriction. Nonetheless, the consistent positive impact suggests a more complex relationship between this screening tool and the demographics of recent hires than one would expect based on exclusion alone.

\section{Employment Based Prisoner Reentry Programs: Do We Know What Works?}

With the tremendous increase in U.S. incarceration rates and the consequent increase in the annual outflow of prison inmates, reentry services are receiving increasing attention from researchers and policymakers. An increasing minority of U.S. men (and for some demographic sub-groups, the majority) will at some point face the challenge of reintegrating into noninstitutional society after a spell in prison. Identifying effective practices for fostering success in reentry is of paramount importance.

Much of the growth in the U.S. incarceration rate since the mid-1970s is attributable to an increased propensity to use incarceration as punishment as well as an increase in the typical amount of time one can expect to serve conditional on the crime committed and on being sent to prison (Raphael and Stoll 2009). However, an increase in the rate at which those conditionally released from prison fail and are returned to custody has also played a fairly large role. To illustrate this fact, Table 11 presents estimates of annual transition probabilities between three possible states of being: (1) not incarcerated and not on parole, (2) incarcerated, and (3) on parole. I use data from the National Prisoner Statistics data base measuring beginning year prison population as well as parole population counts and aggregate annual releases and admissions to estimate these transition probabilities for 1980 and for 2005.

A comparison across the two panels in Table 11 reveals two large changes. First, the transition probability from not incarcerated/not on parole to incarcerated increases nearly 2.8 
times, from 0.00063 to 0.00174 . This probability corresponds to the admissions rate into prison out of the general population not under the supervision of the criminal justice system. Second, the annual rate at which those on parole fail and are returned to custody increases by a factor of 2.2, from 0.13 to $0.29 .^{11}$ This latter transition probability is one stark indicator of an increasing likelihood of failed prisoner reentry.

The transition matrices in Table 11 can be used to illustrate the importance of failed reentry as a contributor to growth in incarceration. Specifically, the probability matrices can be used to solve for steady-state values of the proportion of the population in each possible state. Multiplying the proportion in prison by 100,000 yields the steady-state incarceration rate (as conventionally measured by researchers and by the U.S. Bureau of Justice Statistics) consistent with the transition probabilities of each matrix. ${ }^{12}$ Figure 3 displays these steady-state values for 1980 and 2005. The steady-state incarceration rate increases over this time period from 167 per 100,000 to 553 per 100,000. This predicted increase of 386 inmates per 100,000 exceeds the

\footnotetext{
${ }^{11}$ Note, the figures in Table 11 do not reveal a large decrease in the transition probability out of prison , what one would expect if the average amount of time served were to have increased. In fact, if we sum the two transition probabilities out of incarceration (either due to unconditional release or conditional release) the annual release rate increased from 0.47 to 0.49 , suggesting that the typical term served in prison actually declines over this period. Such an inference however, fails to account for the change in the composition of prisoners. Over this time period the composition of the incarcerated shifts markedly away from violent and property offenders to those convicted of drug crimes and those serving additional time on parole violations. These latter two groups generally serve shorter sentences than the former two groups. If one conditions on crime committed, the release probability does indeed decline over this time period. In all, an increase in the expected value of time served conditional on crime committed and conditional on being sent to prison likely explains a third of the increase in incarceration over the past few decades (Raphael and Stoll 2009).

${ }^{12}$ I calculate the steady-state incarceration rates in the following manner. To begin, define the column vector $P_{t}$ as the three by one vector with elements equal to the population shares in each possible state for year t. The sum of all three elements must equal one for any given year. Define the matrix $\mathrm{T}$ as the transition probability matrix where each element, $T^{i j}$, gives the probability of transitioning from state $i$ to state $j$ over a given time period (in this case, a year). The proportional distribution of the U.S. population across the three states in any given year can be rewritten as a linear function of the state distribution in the previous year and the transition probability matrix, or $P_{t+1}=T^{\prime} P_{t}$. Assuming a stable $\mathrm{T}$, the system reaches the steady-state when applying the transition matrix to the population share vector at the beginning of the year yields the same population distribution at the beginning of the subsequent year. That is to say, in steady state, it must be the case that $P_{t}=P_{t+1}=P$ where we drop the time subscript to indicate the steady state value. When combined with $\mathrm{T}$, this gives the steady state condition $P=T P$. This latter equation in conjunction with the condition that all elements of $P$ must sum to one can be used to derive the steady-state shares for all elements in $P$.
} 
actual increase observed over this period (an actual change of 351 per 100,000). The two figures, however, are of similar magnitude. ${ }^{13}$

For the purposes of benefit-cost analysis, one might be interested in assessing how the increase in the parole failure rate has impacted the national incarceration rate. Alternatively, one might be interested in simulating how an intervention that would reduce the parole failure rate by a given amount would impact the national incarceration rate (and by extension, expenditures on corrections). Figure 3 presents alternative steady-state calculations for 2005 substituting various counterfactual parole failure rates. First, I substitute the transition probabilities from parole for 1980 into the 2005 matrix. Doing so yields a counterfactual steady-state incarceration rate of 427, nearly 30 percent lower than the actual rate for 2005.

I also calculate the steady-state rates under two alternative counterfactuals: (1) a reduction in the parole failure rate of five percentage points, and (2) a reduction in the parole failure rate of 10 percentage points. For both scenarios, I assume equal size increases in the probability of successfully transitioning off parole and the probability of remaining on parole into the next year. ${ }^{14}$ These simulations suggest that interventions that have even modest impacts on the parole failure rate could lead to substantial reductions in the prison population. The five percentage point reduction leads to decline in the steady-state incarceration rate of 40 per 100,000 (7 percent relative to the original 2005 value). A ten-percentage point reduction yields a decline in the steady-state incarceration of 77 per 100,000 (a 14 percent decline).

\footnotetext{
${ }^{13}$ In both years, the steady-state values exceed the actual values. In 1980, the steady-state value of 167 exceeds the actual incarceration of 140 by roughly 17 percent, while in 2005 the steady-state value of 553 exceeds the actual value of 491 by 11 percent. The fact that the steady-state value exceeds the actual value yields the prediction that the national incarceration rate in each year is in the midst of a dynamic adjustment process towards the higher steady-state rate. Raphael and Johnson model this dynamic adjustment process and the likely implications for crime rates (Raphael and Johnson 2008).

${ }^{14}$ Note the rows of the transition probability matrices must sum to one.
} 
The impact of successful reentry programs on the incarceration rate and corrections expenditures along with the social cost savings associated with consequent reductions in victimization costs suggest that the payoffs to effective reentry programs are potentially quite high. What does existing research tell us about reentry efforts to date? Are there identifiable best practices that can be replicated on a large scale to aid reentry and reduce the U.S. incarceration rate through post-release programming? In this section, I address these questions.

\section{Empirical evaluations of prisoner reentry programs: results from non-experimental evaluations}

Given the fractious nature of corrections in the United States (there are 51 independent corrections systems), there are a multitude of programs designed to aid reentry of released prison inmates or minimize criminal activity through the delivery of various services. In many instances these programs are sanctioned and funded by state governments and coordinate service delivery with state parole and local probation departments. Many such programs also receive funding from various federal government agencies and in some instance private foundations.

As there is no standard set of reentry services delivered across the country, there are literally hundreds of alternative programs and approaches ranging from cognitive behavioral therapy, to family reunification services, to employment services of all forms for released inmates and high risk individuals. Consequently, there are also hundreds of empirical evaluations of these efforts.

Nearly all of these evaluations make use of non-experimental techniques. In their exhaustive meta-analysis of all English-language evaluations of prisoner reentry and crimeabatement programs, Drake, Aos, and Miller (2009) identify 545 such program evaluations. Less than five percent of these evaluations utilize a randomized-control research design. Not 
surprisingly, the central tendencies of large meta-analyzes based on non-experimental studies tend to find much larger impacts of program interventions on criminal offending than do the experimental evaluations (contrasting the results in Drake, Aos, and Miller (2009), Aos, Drake, an Miller (2006) and Wilson, Gallagher, and MacKenzie (2001) with the experimental studies reviewed below). This difference may certainly be due in part to the inability of the nonexperimental research to adequately address selection bias due to unobserved differences between program participants and non-participants. However, heterogeneity in the impact such programs have on participants coupled with substitution among randomized control group members towards other available interventions may also explain these disparities (Heckman and Smith 1995).

Clearly, those who stand to benefit the most from receiving reentry services following release from prison should be the most likely to seek out such services. Whether or not one is randomized into the treatment group of a specific program does not preclude those with potentially large gains from seeking out services elsewhere, especially when there are many small competing service providers. In practice, most existing programs are more likely to serve individuals who wish to participate. Those who are induced to participate through random assignment into a treatment group are likely to be compositionally different from those who seek out services on their own. In other words, the program effect for the participant on the margin may be considerably smaller than the impact for the infra-marginal participant, a fact that is also consistent with the disparity between experimental and non-experimental research findings. Many of the experimental studies do not estimate the impact of the intervention on incremental 
service delivery, and generally do not attempt to estimate the distribution of effects sizes beyond the average impact. ${ }^{15}$

Drake, Aos, and Miller (2009) provide the most up-to-date and complete meta-analysis of anti-crime programs that operate through service delivery to either former inmates or high-risk individuals such as disadvantaged youth. The authors searched for all English language evaluations conducted since the 1970s that met three broad criteria: (1) each evaluation had to make use of a comparison sample with reasonable balance on observable covariates between the treatment and comparison groups, (2) evaluations had to include program dropouts as well as program completers in the tabulation of effect sizes, and (3) the evaluation must contain estimates for an impact of some indicator of criminal activity, be it self-reported, arrest, conviction etc. Using all available evaluations that meet these criteria coupled with a standardization of effect size that attenuates effect estimates for studies with relatively less rigorous methodological design, ${ }^{16}$ the authors estimate the average impact on the criminal outcome for over 50 prototypical in-prison and post-prison interventions.

\footnotetext{
${ }^{15}$ Heckman, Smith and Clement (1997) evaluate alternative methods for uncovering heterogeneity in the program effects of experimental interventions. In addition to using probability theory to bound the distribution of program effects (discussed as well in Heckman and Smith 1995), the authors present a model for incorporating information on the program participation decision with the aim of extrapolating the distribution of program effects in an environment when such impacts are likely toe be heterogeneous. Djebbari and Smith (2008) apply these methods to a re-evaluation of the Mexican conditional-cash-transfer program, Progressa, and find strong evidence of systematic heterogeneity.

${ }^{16}$ The authors developed a five-point scale with higher values indicating a stronger methodological design. A score of five was assigned to randomized-control studies. Studies employing quasi-experimental research designs with good balance on covariates between the treatment and control samples that adjust for observable differences between treatment and comparison observations were assigned a score of four. The authors note that convincing instrumental variables studies, regression-discontinuity studies, as well as natural experiments fall into this grouping. Other rigorous quasi-experimental studies with less convincing identification strategies were assigned a value of three. A two was assigned when pre-treatment values for covariates and outcomes are imbalance between the comparison and treatment groups while a value of one was assigned to studies that did not employ a comparison group. The authors only include studies with a value of three or higher. In the meta-analysis, effect sizes for group three studies are discounted by 50 percent while effect sizes for group four studies are discounted by 25 percent. Group five effect sizes are not discounted.
} 
The meta-analysis yields fairly large average effects of in-prison vocational and basic education programs (on the order of nine percent reductions in criminal activity among the treated $)^{17}$. The authors also find an impact of roughly seven percent of in-prison cognitive behavioral therapy. Such therapy focuses on the thoughts, assumptions, and beliefs of the criminally active, with the aim of identifying thought patterns leading to negative behaviors and imparting participants with the tools for correcting these thought processes (National Research Council 2008). Post-release workforce development efforts are also found to reduce criminal offending by roughly five percent.

\section{Results from experimental evaluations of employment-based programs}

Over the past three decades, there have been a handful of experimental evaluations of programs that are intended to reduce criminal activity and foster employment among either former inmates or high-risk groups. The meta-analysis by Visher et al. (2005) identify all such experimental evaluations occurring in the United States through the late 1990s. Here I review the results of this research along with findings from a few recent experimental studies of prisoner reentry efforts.

There have been several evaluations aimed at assessing whether income support for released inmates reduces recidivism rates. The Living Insurance for Ex-Prisoners (LIFE) program was carried out in Baltimore between 1972 and 1974 and evaluated by Maller and Thornton (1978) (and discussed in detail in Rossi, Berk and Lenihan 1980). The target population was former inmates with a very high likelihood of future arrest for a property crime

\footnotetext{
${ }^{17}$ The estimates of criminal activity vary considerably across the studies included in this meta-analysis, although most are based on post-treatment arrests and convictions. The studies also vary according to the follow-up time periods of analysis. The authors include the estimated impact on the longest follow-up period reported in each study.
} 
and no history of drug or alcohol dependence returning from prison to the Baltimore area. The program defined four treatment groups. The first group received a \$60 check once a week for 13 weeks along with job placement assistance. In theory, benefits were suppose to be reduced with increases in labor income at a benefit reduction rates less than one, but in practice all men received the full amount of their grant within thirteen weeks or shortly thereafter. Any unused allocation at the end of the $13^{\text {th }}$ week could be collected within the period of a year post release. The second group received financial assistance but no job placement services. The third group received unlimited job placement services only. The final group provided the controls.

Among those receiving financial assistance, arrests for property crimes were 8.3 percentage points lower (significant at 5 percent) and the proportion not arrested over the subsequent year was 7.4 percentage points higher. There was no statistically significant effect of treatment on employment, where the presumption was that the program created very large negative incentives against working (see the discussion in chapter 2 of Rossi, Berk, and Lenihan 1980). There were also no measurable benefits from receiving job placement assistance. ${ }^{18}$

Based on these findings, the Temporary Aid Research Project (TARP) implemented an income-support program on a larger scale (Rossi, Berk and Lenihan 1980). A key difference relative to the LIFE program, however, was that the program was administered through the state agencies handling unemployment insurance claims. This was meant to mimic how such a program would actually operate if institutionalized by a specific state. In addition, treatment groups were defined to create variation in benefits length as well as benefit reduction rates, and the programs were implemented in different states (Georgia and Texas). The TARP program contained five randomized treatment groups. Three of the groups received financial assistance

\footnotetext{
${ }^{18}$ In a linear probability model of post-treatment arrest, Mallar and Thorton (1978) estimate a marginal effect of job placement assistance of 0.053 with a standard error of 0.0418 in a model controlling for being assigned to receive financial assistance, a quadratic in age, having at least a high school degree, and a dummy indicating white.
} 
(one for 26 weeks with 100 percent benefit reduction rate, one for 13 weeks with a 100 percent benefit reduction rate, and one for 13 weeks with a 25 percent benefit reduction rate) with the provision that unused allotment at the end of the specified period could be used for a period of up to a year. A fourth group was offered employment services only. A fifth group was offered nothing but payment for the interviews. Finally, a sixth group was also identified that was not interviewed but for whom administrative records were analyzed.

The evaluators found no effect of the intervention on arrests, either overall or for specific crimes, in either state. However, there were substantial negative impacts of the program on employment. The authors speculate that the lack of an impact on arrests reflects offsetting impact on criminal activity of (1) the decline in employment (leading to more criminal activity) and (2) the transition aid leading to less criminal activity.

A number of studies have evaluated the impact of providing transitional jobs on the employment and criminal activity of high risk populations. The National Supported Work (NSW) intervention, implemented during the 1970s, targeted four hard-to-employ groups: longterm welfare recipients, ex-offenders defined as those convicted and incarcerated for a crime in the last six months, drug-addicts defined as those currently enrolled in a drug treatment program, and high school dropouts. The original evaluation was carried out by the Manpower Development Research Corporation (1980). While the original evaluation distinguishes drug addicts from ex-offenders, it is likely the case that there was a fair degree of overlap among these groups. Ninety percent of the ex-addicts had prior arrests with the average participants having served non-trivial amounts time. The selection criteria were chosen to ensure selection of the most disadvantaged in terms of labor market prospects. Regarding ex-offenders, the eligibility criteria were "age 18 or older; incarcerated within the last 6 months as the results of a 
conviction." For ex-addicts, the criteria were "age 18 or older; enrolled in a drug treatment program currently or within the preceding 6 months.”

The program provided transitional jobs in work crews with "graduated stress" in terms of productivity and punctuality requirements as time on the program increased. Participants were time limited in terms of how long they could remain employed in the transitional job, with the limits varying across sites from twelve to eighteen months. The impacts differ substantially by participant type. The long-term AFDC recipients experienced significant increases in employment after leaving their supported-work jobs. To be specific, by the last quarter of the follow-up period (25 to 27 months after enrolment), quarterly employment rates for AFDC treatment members exceeded that of the control group by 7.1 percentage points. By this point, none of the treatment group members were employed in a transitional supported-work job. They also experience significant increases in earnings and wages and significant decreases in welfare benefits receipt.

For former addicts, there was a delayed impact on post-transitional-jobs employment, with significant and substantial increases (on the order of 10 percentage points) in employment up to two years after leaving the program. In a series of comparisons of cumulative arrests and convictions post random assignment, the researchers find significant impacts on the amount of criminal activity committed by former addicts, with much of the program impact appearing to coincide with being employed. Finally, there was very little evidence of any impact in any domain for the ex-offender group.

Uggen (2000) reanalyzes the data from the NSW demonstration with an explicit focus on heterogeneity in effect size by age. Unlike the initial evaluation, Uggen pools all respondents with a prior criminal history and analyzes the impact of being assigned to placement in a 
transitional job on the arrest hazard and the likelihood of earning illegal income. After stratifying the treatment groups into those 26 and under and those 27 and over, Uggen finds no treatment effect for the younger group but quite large effects on arrests for the older group (on the order of 10 percentage points on the cumulative arrest probability by the end of three years).

A more recent effort to provide transitional employment to former inmates is the Center for Employment Opportunities (CEO) program based in New York City. Researchers at MDRC are in the process of conducting a multi-year evaluation of this program. The CEO program provides transitional employment to former inmates coupled with basic educational services (when needed) as well as other forms of social support. Participants work in crews and perform services for various public and private sector clients. Participation among those assigned to the treatment group is high (roughly 70 percent) and the typical participant remains in a transitional job for about 18 weeks. Once a participant demonstrates stability and solid work skills, a CEO staff member facilitates the transition to a regular employer.

The evaluations of this program show large impacts on employment for the first three quarters post random-assignment (Bloom et al. 2007). These effects are due entirely to a high propensity to be employed in CEO-provided transitional jobs in the treatment group. By the fourth quarter following assignment, the difference in employment rates between the treatment and control groups disappears.

Regarding recidivism, the one-year evaluation found little impact for most participants but did find a substantial effect for participants receiving services within three months of release (Bloom et al. 2007). This pattern is consistent with the time-profile of the post-release failure hazard. One aspect of the evaluation's design that bears mentioning is that program participants were drawn from individuals who had been referred to CEO by their parole officer. Many of 
these individuals arrived at CEO many months after being released from prison. It is a wellknown fact that the return-to-custody hazard among released inmates spikes within a few months of release and declines quite sharply thereafter (NRC 2008). Thus, a program targeted at individuals who have survived the high hazard period may not yield as large an impact as an intervention targeted at those who have just been released.

The evaluation of second-year results yielded a more broad-based impact of the intervention on criminal activity. Redcross et al. (2009) find that in the second year after randomization, treatment group members were 7.7 percentage points less likely to be convicted of a crime (with most of the difference due to misdemeanor offenses) and 7 percent less likely to have experienced a post release incarceration in either prison or jail. MDRC is currently evaluating similar transitional jobs programs at five other sites across the country.

A number of programs have been targeted at what one might consider high risk individuals that may have already offended and done time or who have a high likelihood of offending. Some of these efforts were not specifically designed to reduce recidivism or the likelihood of participation in criminal activity, yet treated many individuals who would be the target recipients of such efforts. For example, among the groups targeted by the national Job Training Partnership Act (JTPA) evaluation were out-of-school youth (Bloom et al. 1994).

The evaluation used a randomized-control design to evaluate the labor market impacts of the workforce development services offered under JTPA. The evaluation randomized eligible program applicants to either a treatment or control group at a non-random set of 16 service delivery areas between 1987 and 1989. For all participants, the impact of treatment on earnings 
and employment were estimated for the two-and-a-half years following randomization. ${ }^{19}$ The study looked specifically at four target groups: adult men, adult women, and out of school youth of each gender. For out-of-school youth, the evaluation also assessed the impact of the program on self-reported arrest.

One useful aspect of this evaluation was the collection of data on the receipt of alternative services by control group members. Accounting for control-group substitution towards other services as well as incomplete take-up among those assigned to treatment are taken into account allows estimation of the incremental services delivered as a result of assignment to the treatment group. Heckman et al. 2000 show that a fair proportion of the control group received workforce development service elsewhere while nearly a third of the treatment group did not take up. While, assignment to the treatment group did indeed significantly increases services delivered, the modest impact of the program on earnings and arrests should be considered against the modest incremental service delivery caused by the treatment.

The JTPA program involves what one might consider traditional workforce development programs: on-the-job training, job-search assistance, remedial classroom instruction, occupational training. The program significantly increased GED completion among high school dropouts (over 10 percentage point effects for adult high school dropouts). The program also had substantial effects on earnings for adult males and females (intent-to-treat effects of around 8 to 10 percent and treatment-on-the-treated effects on the order of 15 percent). There were no effects of the intervention on the earnings and employment of disadvantaged youth of either gender.

\footnotetext{
${ }^{19}$ The then General Accounting Office (GAO) produced a long term follow-up study in 1996 that estimated program impacts on earnings and employment for five-years post treatment. Much of the positive effects on earnings and employment for adults men and women were found to disappear over this longer term period (see GAO 1996).
} 
The analysis of arrest outcomes for youth was based on self-reports. Among those youth with prior arrests, there was no measurable impact of treatment on arrest. Among male youth who had never been arrested, there was a significant increase in arrests observed for treatment group members (on the order of 5 to 7 percentage points). The authors speculate that this might be the result of the fact that the JTPA program encouraged participants to be forthright about their involvement with the criminal justice system with employers.

The Job Corps provided a much more intensive intervention targeted at high-risk youth (evaluated by Schochet et al. 2001). The Job Corps program is targeted toward disadvantaged youth 16 to 24 years of age. Most participants in the program reside at a Job Corps center (usually over 80 percent) with the average participant staying eight months. Treatment involves a heavy dose of academics, vocational training, and life skills courses. The evaluation randomized a subset of the 80,000 plus Job Corps applicants from 1994 to 1996 to either a control group (that was prohibited from enrolling in Job Corps for four years) or a treatment group that was offered a spot. Roughly 73 percent of the treatment took up. A small portion (around 3 percent) of the control group crossed over (mostly three years post-randomization).

The program had substantial effects on educational attainment and vocational training. Treatment group members completely the equivalent of an additional year of schooling relative to control group members. Given the relationship between educational attainment and offending documented in Lochner and Moretti (2004), this particular aspect of the Job Corp program may explain the factors behind the observed treatment effect on offending. The program also had sizable effects on employment (on the order of 5 percentage points) and earnings for the period starting roughly one year after randomization (most participants left the program within a year of starting). During the first four quarters after randomization, the arrest rate for the treatment 
group was roughly one percentage point lower relative to the control group (relative to control base of 3 to 5 percent). These arrest effects are highly significant. The treatment-on-the-treated estimates of the percent ever arrested or charged is 5.2 percentage points, with 4.2 percentage points occurring in the first year. These are significant at the one percent level. There was a 3 percentage point difference in the proportion convicted over the 48 post-randomization months and 2 percentage point difference in the percent incarcerated. These effect sizes are relative to control baselines of 25.2 and 17.9 percent, respectively. Estimated impacts were substantially larger for men. The arrest treatment effect was 5 percentage points, the convicted treatment effect was 4 percentage points, while the incarcerated treatment effect was 3.1 percentage points, all significant at the 5 percent level. There were no significant effects for females or for male non-residents.

It is noteworthy that in contrast to the JTPA evaluation, Job Corps delivered significant impacts on both employment as well as criminal offending for youth. The large impact on educational attainment may have been one important mediating factor. Clearly, the residential component of the program is likely to have been important as well, as this aspect of the program likely removed youth from social networks that may have enhanced the likelihood of poor outcomes. Despite the high costs associated with this program, it is notable that cost-benefit analysis accompanying the official evaluation concludes that Job Corps passes the cost-benefit test. Most of the benefits occur in the form of the value of increased productivity as well as a reduction in service use among program participants (McConnell and Glazerman 2001)

The JOBSTART program is largely patterned after the Job Corps program (Cave et al. 1993), the key differences being that JOBSTART does not provide a stipend and JOBSTART is a non-residential program. The program targets 17 to 21 year old school dropouts and delivers 
academic services, occupational and vocational training and job placement services. The randomized-control evaluation of this program was principally concerned with the domains of educational attainment and employment outcomes, though the report also includes information on welfare receipts, fertility, and criminal activity (based on whether one is ever arrested). There is no information on incarceration.

Similar to the results for Job Corps, the program had a large treatment effect on the likelihood of completing a GED or a high school diploma (on the order of 13 percentage points). Treatment group members experienced small declines in employment and earnings in the first post-randomization year (most likely due to the time demands of participation in the program), and slightly higher earnings and employment in all other years. With regards to arrests, the treatment had a fairly large impact on the likelihood of being arrested in the first year for male participants (over six percentage points), but no impact on the arrest likelihood at the end of the four-year evaluation.

To summarize the experimental research, there is some evidence that income support, transitional employment, and human capital investments in former and potential future inmates mat reduce criminal behavior and recidivism. The results, however, are not entirely consistent across studies. Perhaps the weakest evidence is observed for income support. There is reason to believe that the small scale intervention under the LIFE program involved very intensive case work among program implementers on behalf of the formers inmates, while delivery of income support through the TARP program occurred at arm's length and involved much more rigorous enforcement of the benefit reductions with labor income. Any large scale implementation of such assistance is perhaps more likely to take the form of the TARP evaluation than the LIFE program, calling into question this approach. Nonetheless, these are the only two experimental 
studies exploring the effects of income support. Such efforts combined with different sets of services or alternative rules regarding interactions with labor income may yield different outcomes.

Transitional employment appears to have particular promise. Moreover, several programs providing transitional employment are being evaluated with a randomized-control design at different locations across the country, thus we are likely to learn much more about such interventions. Both the NSW and CEO evaluations find substantial evidence of heterogeneity in program effect, suggesting that perhaps the hardest to serve are the least likely to benefits. It is somewhat surprising that despite large impacts on employment in the first few quarters post assignment, there is little overall impact on measures of criminal offending in the CEO evaluation. While this may be due to the sampling frame used to generate experimental subjects, this basic patterns for year one is sobering.

Perhaps the brightest prospects are observed for at-risk youth. All of the programs reviewed (JTPA, Job Corps, JOB START) have substantial impacts on the educational attainment of participants, with Job Corp adding nearly a full year of instructional time. The more extensive measures of criminal behavior in Job Corps and JOB START both yielded evidence of substantial impacts of these programs on criminal participation.

\section{Conclusion}

Successfully connecting reentering prison inmates to suitable employment opportunities is a formidable task. Those who end up in U.S. prisons are perhaps among the lowest skilled adults in society, and have a number of personal problems (health and behavioral) that render many of them difficult to employ. Employers exhibit a strong reluctance to hire such workers, 
are increasingly reviewing the official criminal backgrounds of applicants through formal record searches, and are often prohibited by law from hiring convicted felons.

To the extent that difficulty finding a job contributes to parole failure, effective reentry policy may result in substantial social benefits. I have shown that modest declines in parole failure rates can lead to notable declines in incarceration. Given the relatively high variable cost of incarcerating additional felons (as well as the capital costs associated with new prison construction that many states with over-crowded systems are currently facing) and the potential reduction in victimization costs associated with lower offending, the benefits of such interventions clearly extend beyond the benefits accrued by the former inmate himself. What we know about such efforts from experimental evaluations is rather porous and context specific. One does walk away with the impression that such interventions matter and do work, yet the interventions differ considerably across demonstrations (both in program design and implementation). Thus, it is difficult to draw general lessons that would be useful in designing larger scale interventions intended to address the enormity of the current policy challenge. 


\section{References}

Aos, Steve; Miller, Marna G. and Elizabeth K. Drake (2006), "Evidence-Based Public Policy Options to Reduce Future Prison Construction, Criminal Justice Costs, and Crime Rates," (Document 06-10-1201) Olympia, WA: Washington State Institute for Public Policy.

Autor, David H. and David Scarborough (2008), "Does Job Testing Harm Minority Workers? Evidence from Retail Establishments,” Quarterly Journal of Economics, 123(1): 219-277.

Bertrand, Marianne and Sendhil Mullainathan (2004), “Are Emily and Greg More Employable than Lakisha and Jamal?” American Economic Review, 94(4): 991-1013.

Black, Dan (1995), “Discrimination in an Equilibrium Search Model," Journal of Labor Economics, 13(2): 991-1013.

Bloom, Dan; Redcross, Cindy; Zweig, Janine; and Gilda Azurdia (2007), “Transitional Jobs for Ex-Prisoners: Early Impacts from a Random Assignment Evaluation of the Center for Employment Opportunities Prisoner Reentry Program,” MDRC Working Paper.

Bloom, Howard S.; Orr, Larry L.; Cave, George; Bell, Stephen H.; Doolittle, Fred and Winston Lin (1994), The National JTPA Study, Overview: Impacts, Benefits, and Costs of Title II-A, Abt Associates: Bethesda, MD.

Bushway, Shawn D. "Labor Market Effects of Permitting Employer Access to Criminal History Records.” Journal of Contemporary Criminal Justice 20: 276-291 (2004).

Bushway, Shawn D. and Gary Sweeten (2007), "Abolish Lifetime Bans for Ex-Felons," Criminology and Public Policy, 6: 697-706.

Cave, George; Bos, Hans; Doolittle, Fred and Cyril Toussaint (1993), JOBSTART: Final Report on a Program for School Dropouts, MDRC, New York.

Cook, Philip J. (1975), “The Correctional Carrot: Better Jobs for Parolees,” Policy Analysis, 1(1): 11-54.

Djebbari, Habiba and Jeffrey Smith (2008), “Heterogeneous Impacts in PROGRESA,” IZA discussion pape \#3362.

Drake, Elizabeth K.; Aos, Steve and Marna G. Miller (2009), “Evidence-Based Public Policy Options to Reduce Crime and Criminal Justice Costs: Implications in Washington State,” Victims and Offenders, 4: 170-196.

Fix, Michael; Galster, George C.; and Raymond J. Struyk (1993), “An Overview of Auditing for Discriination,” in Michael Fix and Raymund J Struyk (eds), Clear and Convincing Evidence: Measurement of Discrimination in America, Urban Institute Press: Washington, D.C. pp 1-68. 
General Accounting Office (1996), Job Training Partnership ACT: Long-Term Earnings and Employment Outcomes, CAO/HEHS-96-40.

Grogger, Jeff (1998), “Market Wages and Youth Crime,” Journal of Labor Economics, 16(4): 756-791.

Heckman, James; Hohmann, Neil; Smith, Jeffrey and Michael Khoo (2000), "Substitution and Dropout Bias in Social Experiments: A Study of an Influential Social Experiment.” Quarterly Journal of Economics, 115(2): 651-694.

Heckman, James and Peter Siegelman (1993), “The Urban Institute Audit Studies: Their Methods and Findings," in Michael Fix and Raymund J Struyk (eds), Clear and Convincing Evidence: Measurement of Discrimination in America, Urban Institute Press: Washington, D.C. pp 187-276.

Heckman, James and Jeffrey Smith (1995), “Assessing the Case for Social Experiments," Journal of Economic Perspectives, 9(2): 85-110.

Heckman, James; Smith, Jeffrey and Nancy Clements (1997), "Making the Most Out of Programme Evaluations and Social Experiments: Accounting for Heterogeneity in Programme Impacts," Review of Economic Studies, 64: 487-535.

Holzer, Harry J.; Raphael, Steven; and Michael A. Stoll (2006) "Perceived Criminality, Criminal Background Checks and the Racial Hiring Practices of Employers," Journal of Law and Economics, 49(2): 451-480.

Holzer, Harry J.; Raphael, Steven; and Michael A. Stoll (2007), "The Effect of an Applicant's Criminal History on Employer Hiring Decisions and Screening Practices: Evidence from Los Angeles," in Bushway, Shawn; Stoll, Michael and David Weiman (ed.) Barriers to Reentry? The Labor Market for Released Prisoners in Post-Industrial America, Russell Sage Foundation: New York (2007).

Johnson, Rucker and Steven Raphael (2008), "How Much Crime Reduction Does the Marginal Prisoner Buy?” Working Paper, UC Berkeley.

Juhn, Chinhui (2008), "Decline of Male Labor Market Participation: The Role of Declining Market Opportunities," Quarterly Journal of Economics, 107 (1): 79-121.

Lanning, Jonathan A. (2010), "Opportunities Denied, Wages Diminished: Using Search Theory to Translate Audit Pair Study findings Into Wage Differentials," Working Paper, Albion College.

Legal Action Center (2004), After Prison: Roadblocks to Reentry, A Report on State Legal Barriers Facing People with Criminal Records, Legal Action Center, New York. 
Lochner, Lance and Enrico Moretti (2004), "The Effect of Education on Criminal Activity: Evidence from Prison Inmates, Arrest, and Self Reports,” American Economic Review, 94(1): 155-189.

Mallar, Charles D. and Craig V. D. Thornton (1978), "Transitional Aid for Released Prisoners: Evidence from the Life Experiment,” Journal of Human Resources, 13(2): 208-236.

McConnell, Sheena and Steven Glazerman (2001), National Job Corps Study: The Benefits and Costs of Job Corps, Mathematica Policy Research Inc., Princeton, NJ.

MDRC (1980), Summary Findings of the National Supported Work Demonstration, Ballinger Publishing Company, Cambridge, MA.

National Research Council (2008), Parole Desistance from Crime and Community Integration, the National Academy Press: Washington, D.C.

Pager, Devah (2003), “The Mark of a Criminal Record,” American Journal of Sociology, 108(5): 937-975.

Raphael, Steven (2005) "The Socioeconomic Status of Black Males: The Increasing Importance of Incarceration," in Auerbach, Alan; Card, David, and John Quigley (eds.), Poverty, the Distribution of Income, and Public Policy, Russell Sage Foundation: New York.

Raphael, Steven and Michael A. Stoll (2009), “Why Are So Many Americans in Prison?” in Raphael, Steven and Michael Stoll (eds.) Do Prisons Make Us Safer? The Benefits and Costs of the Prison Boom, Russell Sage Foundation, New York.

Redcross, Cindy; Bloom, Dan; Azurdia, Gilda; Zweig, Janine and Nancy Pindus (2009), Transitional Jobs For Ex-Prisoners: Implementation, Two-Year Impacts, and Costs of the Center for Employment Opportunities (CEO) Prisoner Reentry Program, MDRC, New York.

Rossi, Peter; Berk, Richard A. and Kenneth J Lenihan (1980), Money, Work, and Crime:

Experimental Evidence, Quantitative Studies in Social Relations, Academic Press: New York.

Sampson, Robert J. and John H. Laub (2003), "Life-Course Desisters? Trajectories of Crime Among Delinquent Boys Followed to Age 70?” Criminology, 41: 301-339.

Schochet, Peter Z; Burghardt, John and Steven Glazerman (2001), National Job Corps Study: The Impact of Job Corps on Participants' Employment and Related Outcomes, Mathematica Policy Research Inc., Princeton, NJ.

Turner, Margery Austin; Fix, Michael and Raymund J. Struyk (1991), Opportunities Denied, Opportunities Diminished, Urban Institute Report 91-9, Washington D.C. 
Uggen, Christopher (2000), "Work as a Turning Point in the Life Course of Criminals: A Duration Model of Age, Employment, and Recidivism,” American Sociological Review, 67(August): 529-546.

Visher, Christy A.; Winterfield, Laura and Mark B. Coggeshall (2005), "Ex-Offender Employment Programs and Recidivism: A Meta-Analysis,” Journal of Experimental Criminology, 1: 295-315.

Wilson, D. B., Gallagher, C.A. and D. L. MacKenzie (2001), “A Meta-Analysis of CorrectionsBased Education, Vocation, and Work Programs for Adults Offenders," Journal of Research in Crime and Delinquency 37: 347-368.

Wolf-Harlow, Caroline (2003), Education and Correctional Populations, U.S. Bureau of Justice Statistics, NCJ 195670. 


\section{Figure 1}

Cumulative Density Functions of Prison Releases by Their Simulated Position in the Annual Earnings Distribution for All Wage and Salary Workers and Male Wage and Salary Workers

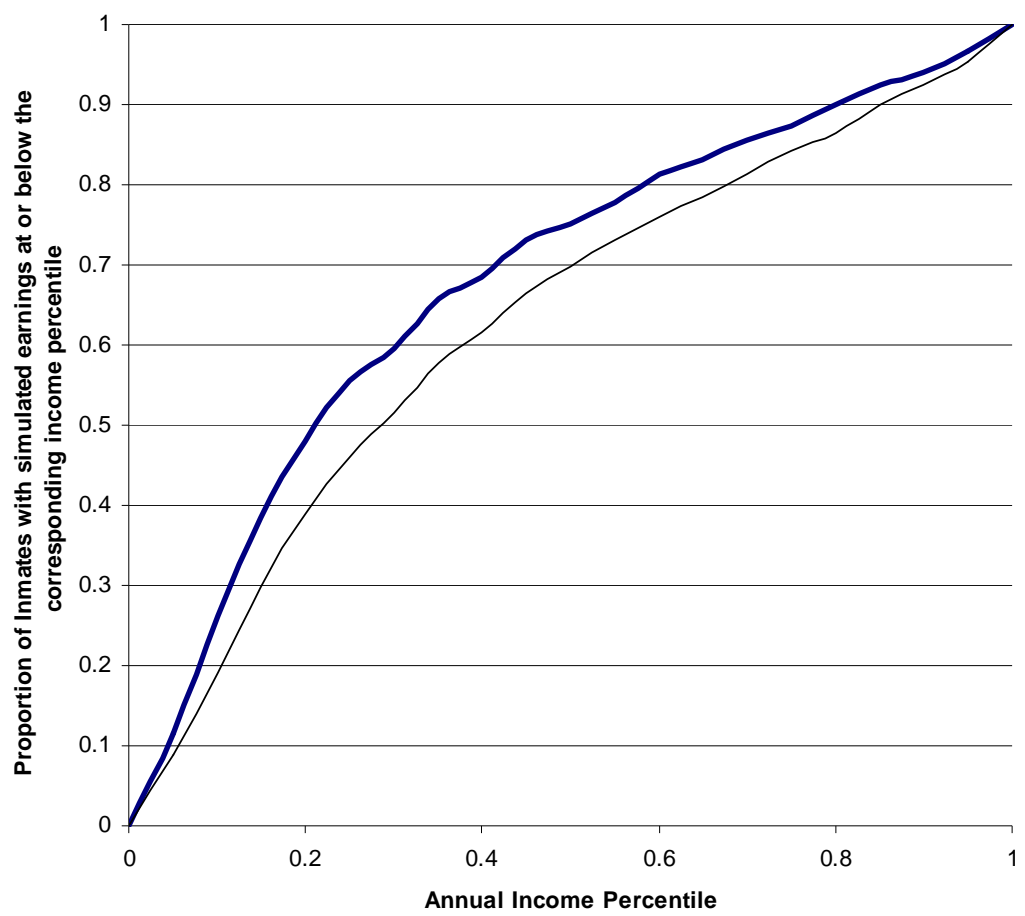

Releases CDF relative to male wage and salary workers

Releases CDF relative to all wage and salary workers

Figure 2

Methods Used to Acquire Information on Applicant Criminal History Records Among Establishments that Check

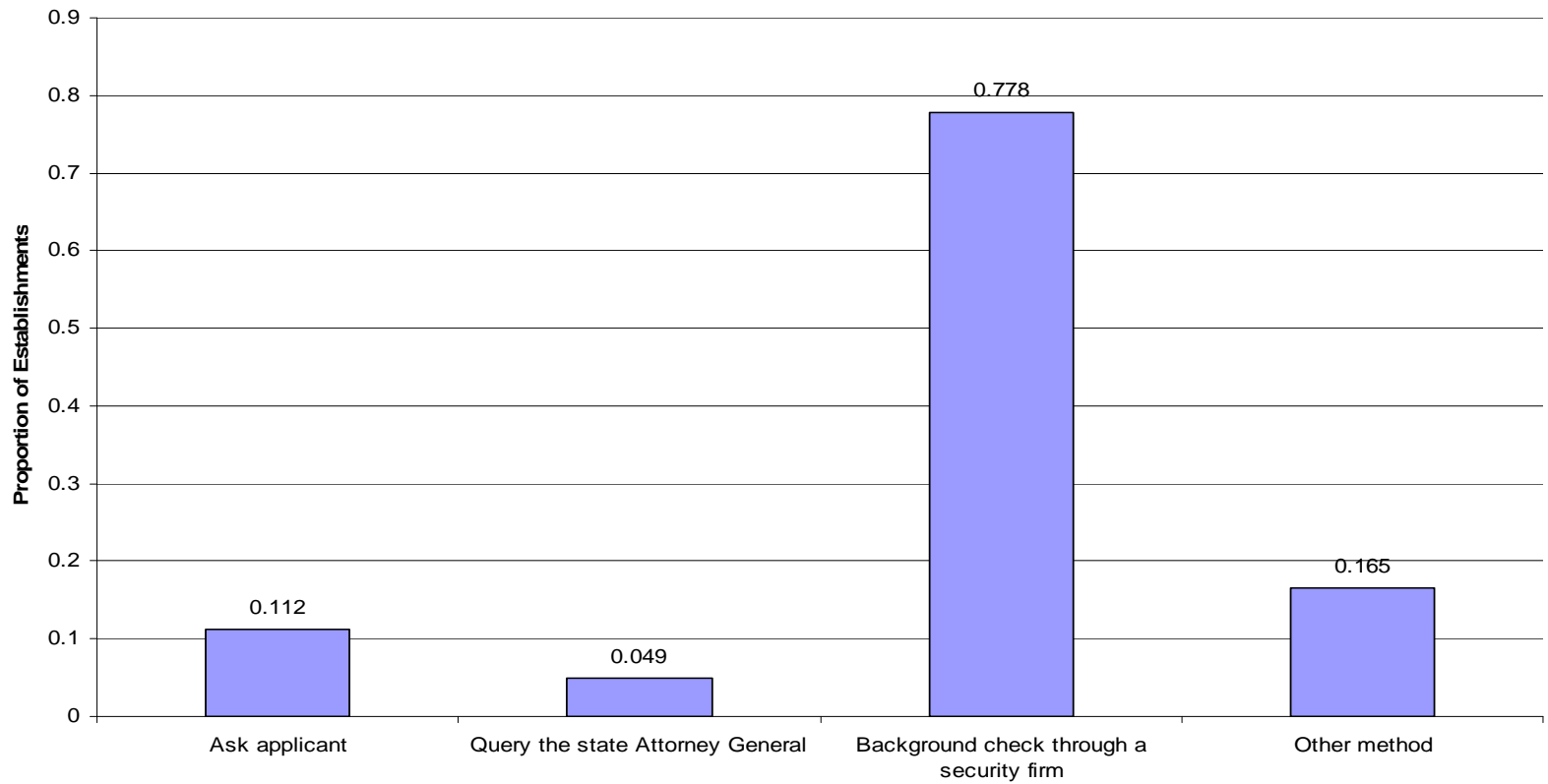


Figure 3

Implied Steady State Incarceration for 1980, 2005, and several counterfactual values for 2005

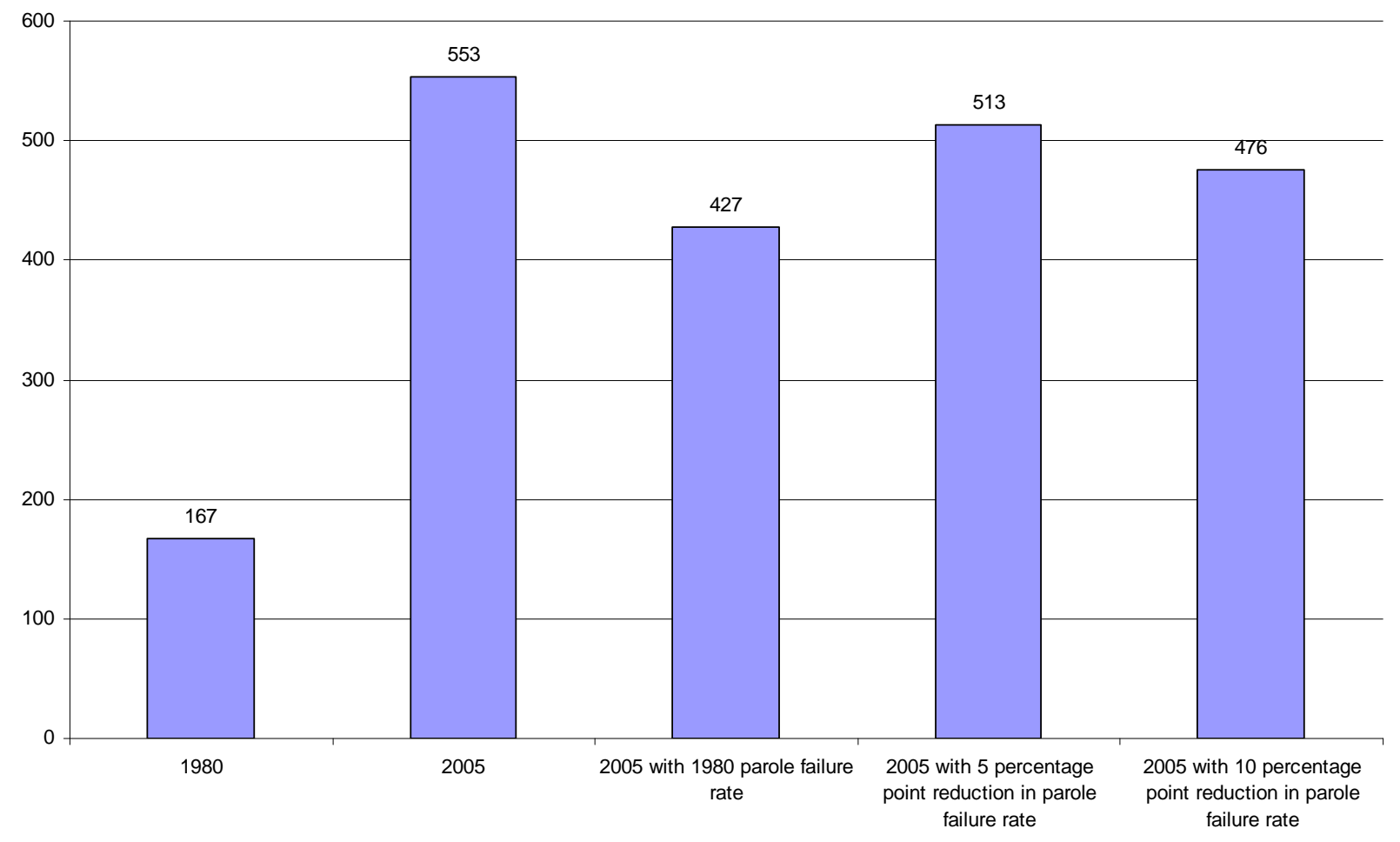




\section{Table 1}

\section{Characteristics of State and Federal Prisoners in 2004}

\begin{tabular}{|c|c|c|}
\hline 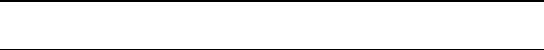 & State Prisoners & Federal Prisoners \\
\hline Proportion of prison & 0.904 & 0.096 \\
\hline & 0.932 & 0.929 \\
\hline \multicolumn{3}{|l|}{ Proportion Male } \\
\hline \multicolumn{3}{|l|}{$\begin{array}{l}\text { Education attainment prior to } \\
\text { admissions }\end{array}$} \\
\hline Elementary school & 0.029 & 0.040 \\
\hline Middle school & 0.165 & 0.143 \\
\hline Some high school, no degree & 0.472 & 0.374 \\
\hline High school graduate & 0.195 & 0.214 \\
\hline More than high school & 0.139 & 0.227 \\
\hline Proportion Hispanic & 0.182 & 0.251 \\
\hline \multicolumn{3}{|l|}{ Race } \\
\hline White & 0.487 & 0.433 \\
\hline Black & 0.430 & 0.460 \\
\hline Other & 0.083 & 0.107 \\
\hline \multicolumn{3}{|l|}{ Age Distribution } \\
\hline $25^{\text {th }}$ percentile & 27 & 29 \\
\hline $50^{\text {th }}$ percentile & 34 & 35 \\
\hline $75^{\text {th }}$ percentile & 42 & 44 \\
\hline \multicolumn{3}{|l|}{ Age at first arrest } \\
\hline $25^{\text {th }}$ percentile & 15 & 16 \\
\hline $50^{\text {th }}$ percentile & 17 & 18 \\
\hline $75^{\text {th }}$ percentile & 21 & 23 \\
\hline \multicolumn{3}{|l|}{$\begin{array}{l}\text { Age first engaged in criminal } \\
\text { activity }\end{array}$} \\
\hline $25^{\text {th }}$ percentile & 12 & 12 \\
\hline $50^{\text {th }}$ percentile & 14 & 14 \\
\hline $75^{\text {th }}$ percentile & 16 & 16 \\
\hline \multicolumn{3}{|l|}{ Health Conditions } \\
\hline Diabetes & 0.047 & 0.061 \\
\hline Heart problems & 0.093 & 0.086 \\
\hline Kidney problems & 0.061 & 0.057 \\
\hline Asthma & 0.144 & 0.115 \\
\hline Hepatitis & 0.095 & 0.076 \\
\hline
\end{tabular}




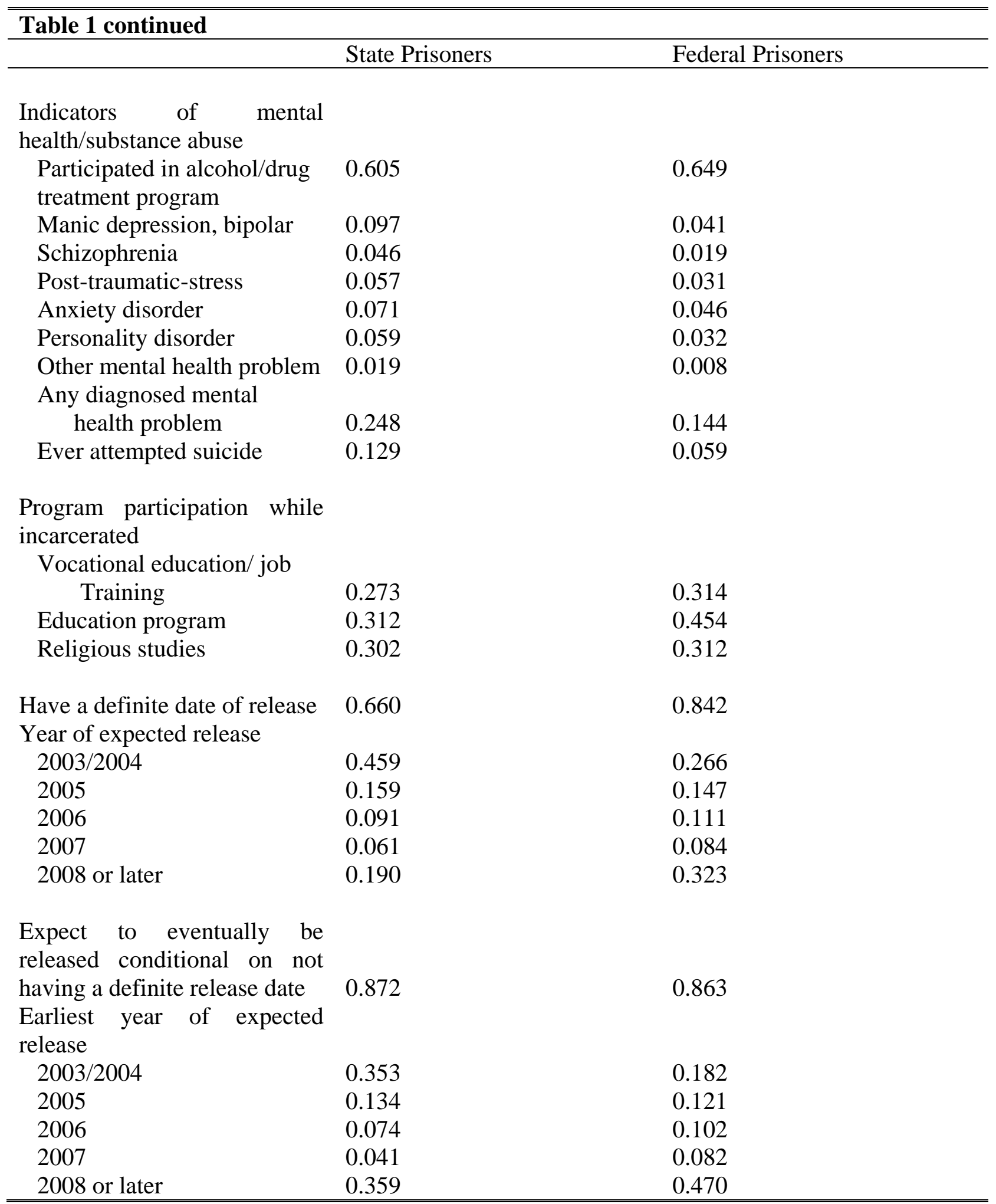

Figures in the table are tabulated from the 2004 Survey of Inmates in State and Federal Corrections Facilities. 


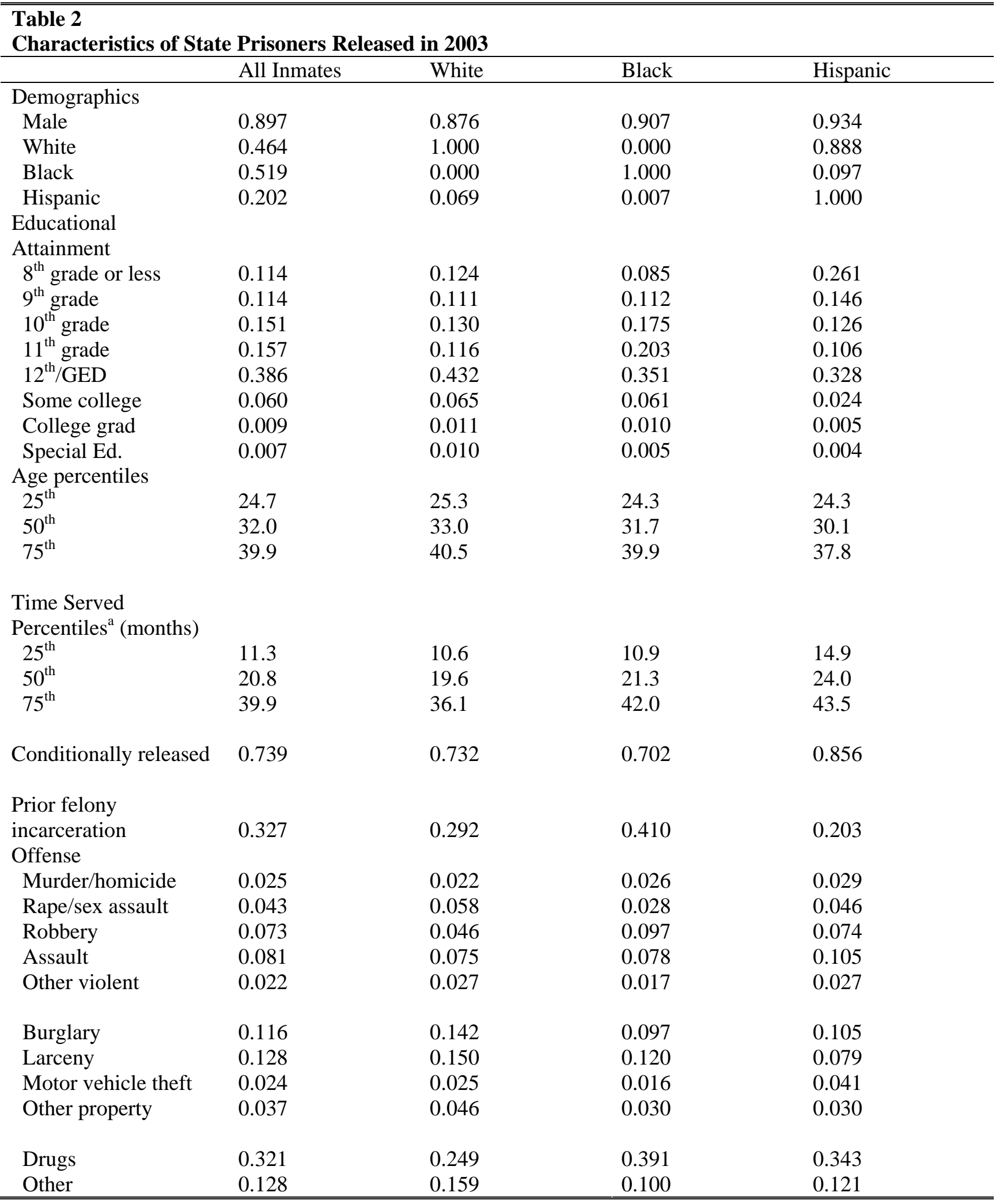

Tabulated from the 2003 NCRP data base.

a. Refers to time served for release offense. 


\begin{tabular}{llll}
\hline \hline $\begin{array}{l}\text { Table } 3 \\
\text { Indicators of Employer Willingness to Hire }\end{array}$ & Workers with Specific & Characteristics into \\
Non-Professional, Non-Managerial Jobs & & \\
\hline $\begin{array}{l}\text { Degree of } \\
\text { acceptability for the }\end{array}$ & Has a criminal record & $\begin{array}{l}\text { Unemployed for a } \\
\text { year or more }\end{array}$ & $\begin{array}{l}\text { Minimal work } \\
\text { experience }\end{array}$ \\
$\begin{array}{l}\text { most recently filled } \\
\text { position }\end{array}$ & & \\
\hline $\begin{array}{l}\text { Definitely accept } \\
\text { Probably accept }\end{array}$ & 0.018 & 0.077 & 0.090 \\
$\begin{array}{l}\text { Probably no accept } \\
\text { Definitely no accept }\end{array}$ & 0.271 & 0.538 & 0.318 \\
\hline \hline
\end{tabular}

All figures are tabulated from the 2003 Survey of California Establishments. 


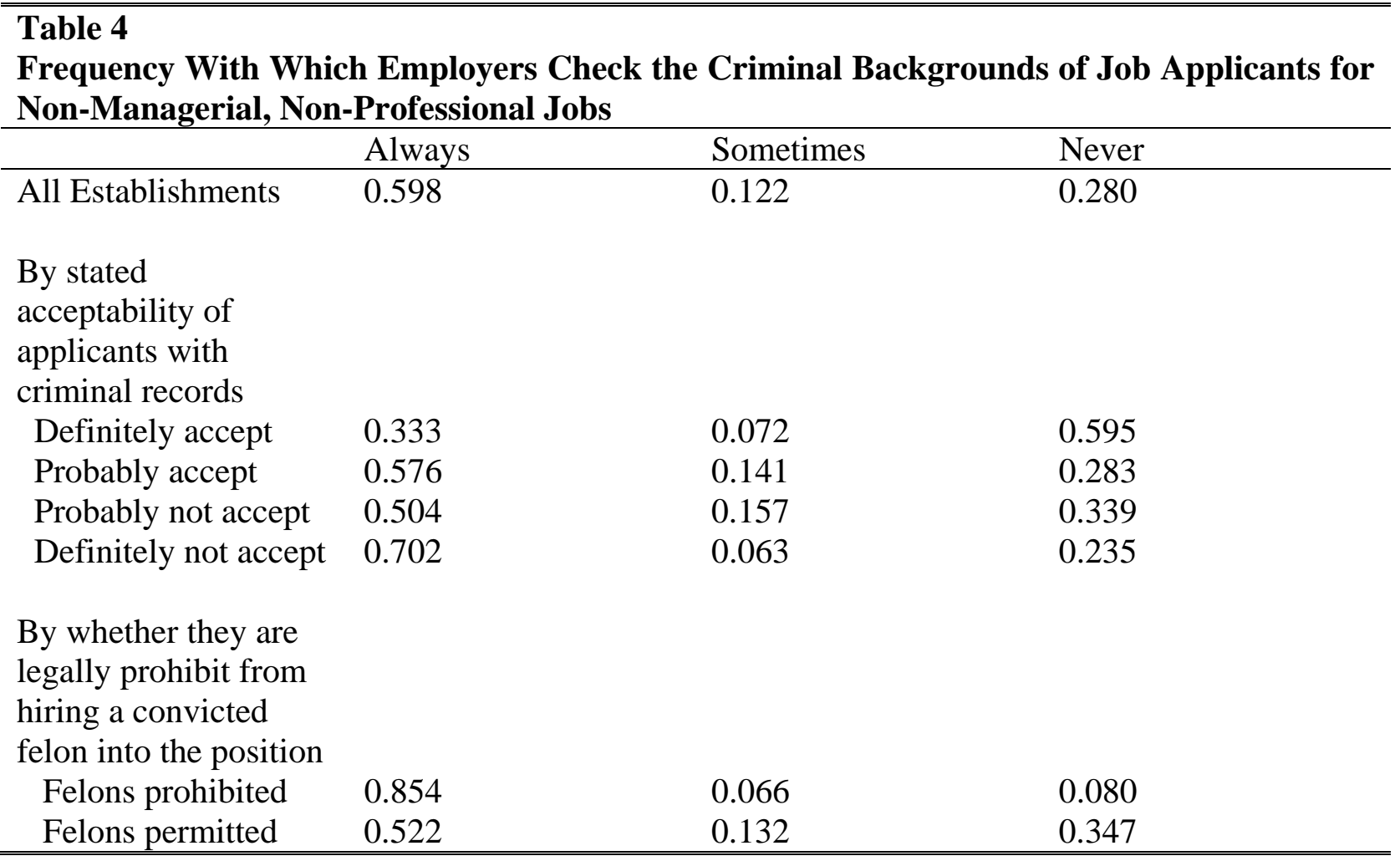

All figures are tabulated from the 2003 Survey of California Establishments. 


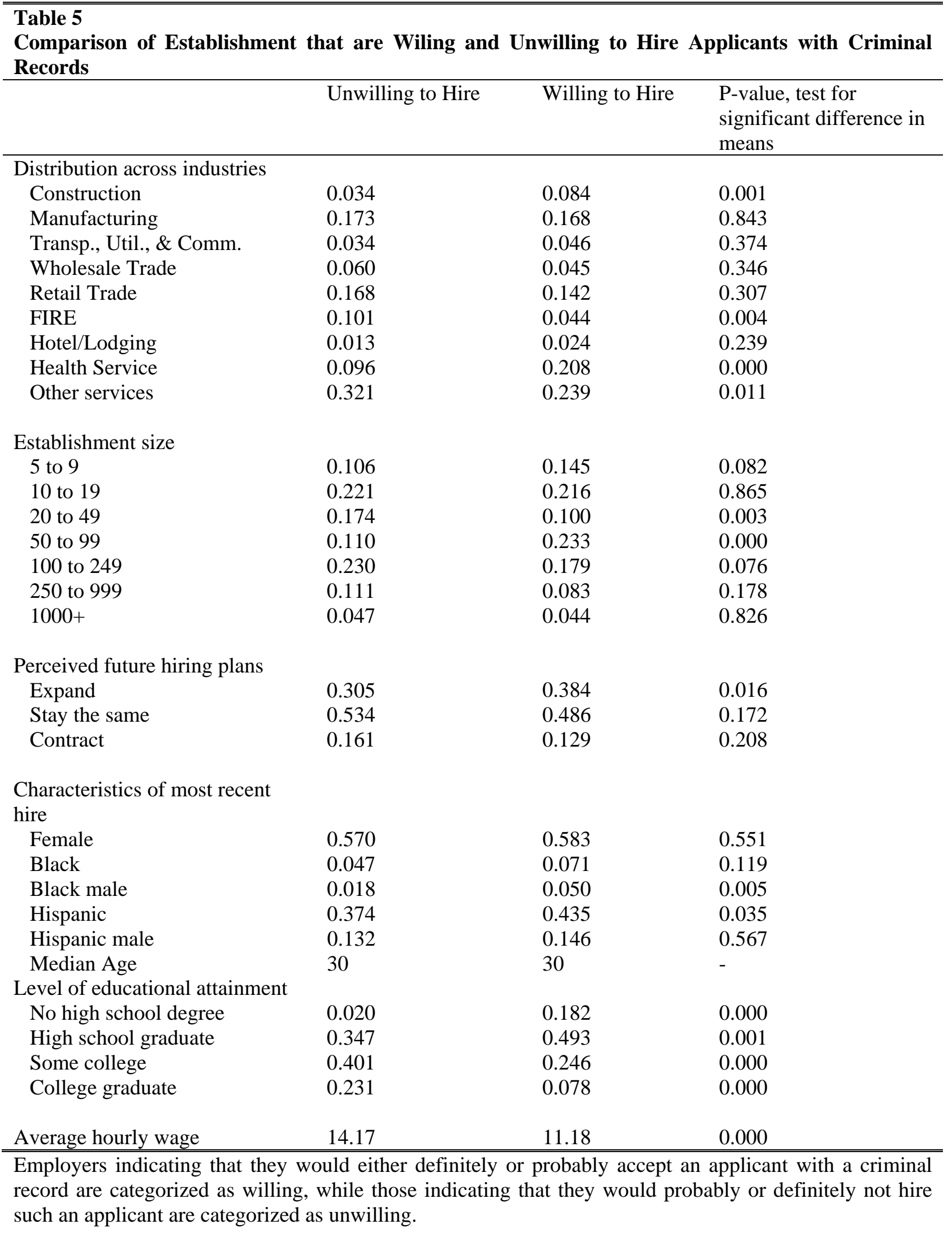




\begin{tabular}{|c|c|c|c|}
\hline $\begin{array}{l}\text { Table } 6 \\
\text { Comparison of Establish } \\
\text { that are not Legally Proh }\end{array}$ & are Prohibited from & Iiring Convicted & elons to Establishments \\
\hline & $\begin{array}{l}\text { Not Prohibited from } \\
\text { hiring convicted felons }\end{array}$ & $\begin{array}{l}\text { Prohibited from } \\
\text { hiring felons }\end{array}$ & $\begin{array}{l}\text { P-value, test for } \\
\text { significant difference in } \\
\text { means }\end{array}$ \\
\hline Distribution across industri & & & \\
\hline Construction & 0.055 & 0.030 & 0.130 \\
\hline Manufacturing & 0.214 & 0.067 & 0.000 \\
\hline Transp., Util., \& Comm. & 0.041 & 0.035 & 0.706 \\
\hline Wholesale Trade & 0.062 & 0.017 & 0.007 \\
\hline Retail Trade & 0.182 & 0.060 & 0.000 \\
\hline FIRE & 0.081 & 0.108 & 0.215 \\
\hline Hotel/Lodging & 0.019 & 0.012 & 0.541 \\
\hline Health Service & 0.113 & 0.206 & 0.000 \\
\hline Other services & 0.234 & 0.464 & 0.000 \\
\hline Establishment size & & & \\
\hline 5 to 9 & 0.124 & 0.065 & 0.013 \\
\hline 10 to 19 & 0.189 & 0.297 & 0.000 \\
\hline 20 to 49 & 0.148 & 0.118 & 0.247 \\
\hline 50 to 99 & 0.149 & 0.121 & 0.285 \\
\hline 100 to 249 & 0.245 & 0.215 & 0.352 \\
\hline 250 to 999 & 0.103 & 0.114 & 0.643 \\
\hline $1000+$ & 0.043 & 0.071 & 0.082 \\
\hline Perceived future hiring pla & & & \\
\hline Expand & 0.344 & 0.278 & 0.060 \\
\hline Stay the same & 0.476 & 0.659 & 0.000 \\
\hline Contract & 0.180 & 0.062 & 0.000 \\
\hline $\begin{array}{l}\text { Characteristics of most rec } \\
\text { hire }\end{array}$ & & & \\
\hline Female & 0.572 & 0.724 & 0.000 \\
\hline Black & 0.023 & 0.081 & 0.000 \\
\hline Black male & 0.011 & 0.041 & 0.002 \\
\hline Hispanic & 0.389 & 0.367 & 0.549 \\
\hline Hispanic male & 0.151 & 0.081 & 0.007 \\
\hline Median Age & 30 & 30 & - \\
\hline Level of educational attain & & & \\
\hline No high school degree & 0.080 & 0.017 & 0.001 \\
\hline High school graduate & 0.417 & 0.282 & 0.002 \\
\hline Some college & 0.293 & 0.510 & 0.000 \\
\hline College graduate & 0.211 & 0.192 & 0.646 \\
\hline Average hourly wage & 13.10 & 14.54 & 0.011 \\
\hline
\end{tabular}




\begin{tabular}{|c|c|c|c|}
\hline \multicolumn{4}{|c|}{$\begin{array}{l}\text { Table } 7 \\
\text { Comparison of Establishment that Do Not Check the Criminal History of Applicants to Those that } \\
\text { Do }\end{array}$} \\
\hline & $\begin{array}{l}\text { Don’t Check Criminal } \\
\text { Histories }\end{array}$ & $\begin{array}{l}\text { Check Criminal } \\
\text { Histories }\end{array}$ & $\begin{array}{l}\text { P-value, test for } \\
\text { significant difference in } \\
\text { means }\end{array}$ \\
\hline \multicolumn{4}{|l|}{ Distribution across industries } \\
\hline Construction & 0.073 & 0.034 & 0.006 \\
\hline Manufacturing & 0.153 & 0.211 & 0.032 \\
\hline Transp., Util., \& Comm. & 0.021 & 0.049 & 0.036 \\
\hline Wholesale Trade & 0.104 & 0.036 & 0.000 \\
\hline Retail Trade & 0.267 & 0.121 & 0.000 \\
\hline FIRE & 0.084 & 0.083 & 0.968 \\
\hline Hotel/Lodging & 0.018 & 0.016 & 0.797 \\
\hline Health Service & 0.051 & 0.153 & 0.000 \\
\hline Other services & 0.229 & 0.298 & 0.027 \\
\hline \multicolumn{4}{|l|}{ Establishment size } \\
\hline 5 to 9 & 0.161 & 0.091 & 0.001 \\
\hline 10 to 19 & 0.257 & 0.199 & 0.038 \\
\hline 20 to 49 & 0.230 & 0.109 & 0.000 \\
\hline 50 to 99 & 0.119 & 0.158 & 0.110 \\
\hline 100 to 249 & 0.171 & 0.246 & 0.009 \\
\hline 250 to 999 & 0.056 & 0.135 & 0.000 \\
\hline $1000+$ & 0.006 & 0.063 & 0.000 \\
\hline \multicolumn{4}{|l|}{ Perceived future hiring plans } \\
\hline Expand & 0.347 & 0.328 & 0.565 \\
\hline Stay the same & 0.511 & 0.508 & 0.934 \\
\hline Contract & 0.143 & 0.164 & 0.391 \\
\hline \multicolumn{4}{|c|}{$\begin{array}{l}\text { Characteristics of most recent } \\
\text { hire }\end{array}$} \\
\hline Female & 0.519 & 0.603 & 0.103 \\
\hline Black & 0.018 & 0.063 & 0.005 \\
\hline Black male & 0.007 & 0.032 & 0.018 \\
\hline Hispanic & 0.356 & 0.412 & 0.096 \\
\hline Hispanic male & 0.109 & 0.139 & 0.203 \\
\hline Median Age & 28 & 30 & - \\
\hline \multicolumn{4}{|c|}{ Level of educational attainment } \\
\hline No high school degree & 0.046 & 0.067 & 0.201 \\
\hline High school graduate & 0.452 & 0.351 & 0.023 \\
\hline Some college & 0.387 & 0.342 & 0.418 \\
\hline College graduate & 0.116 & 0.241 & 0.000 \\
\hline Average hourly wage & 11.52 & 14.09 & 0.000 \\
\hline
\end{tabular}




\begin{tabular}{|c|c|c|c|c|}
\hline & & & & \\
\hline & (1) & (2) & (3) & (4) \\
\hline Stay the same & $\begin{array}{l}-0.068 \\
(0.032)\end{array}$ & $\begin{array}{l}-0.057 \\
(0.033)\end{array}$ & $\begin{array}{l}-0.049 \\
(0.036)\end{array}$ & $\begin{array}{l}-0.040 \\
(0.039)\end{array}$ \\
\hline Contract & $\begin{array}{l}-0.093 \\
(0.044)\end{array}$ & $\begin{array}{l}-0.093 \\
(0.046)\end{array}$ & $\begin{array}{l}-0.028 \\
(0.054)\end{array}$ & $\begin{array}{l}-0.045 \\
(0.060)\end{array}$ \\
\hline F-statistic & 3.100 & 2.480 & 0.790 & 0.600 \\
\hline (P-value) & $(0.046)$ & $(0.084)$ & $(0.452)$ & $(0.549)$ \\
\hline $\begin{array}{l}\text { Industry and size } \\
\text { dummies }\end{array}$ & No & Yes & Yes & Yes \\
\hline $\begin{array}{l}\text { Industry/size } \\
\text { interaction terms }\end{array}$ & No & No & Yes & Yes \\
\hline $\begin{array}{l}\text { Control for } \\
\text { prohibition } \\
\text { against hiring } \\
\text { felons, whether } \\
\text { the establishment } \\
\text { checks } \\
\text { backgrounds, and } \\
\text { dummies for } \\
\text { education } \\
\text { attainment of } \\
\text { most recent hire }\end{array}$ & No & No & No & Yes \\
\hline
\end{tabular}

Standard errors are in parentheses. Establishments that plan to expand are the omitted category. All models are estimated using a linear probability regression.

a. This is a test statistic and p-value from a test of the null hypothesis that the coefficients on the two variables measuring the establishment's future hiring plans equal zero. 


\begin{tabular}{|c|c|c|c|}
\hline \multicolumn{4}{|c|}{$\begin{array}{l}\text { Table } 9 \\
\text { Multivariate Regression Estimates of the Impact of a Legal Prohibition Against Hiring } \\
\text { Convicted Felons on the Likelihood that the Most Recent Hire Into a Non-Professional, } \\
\text { Non-Managerial Job Is Male, Black, or Hispanic }\end{array}$} \\
\hline $\begin{array}{l}\text { Outcome } \\
\text { Variable }\end{array}$ & Specification (1) & Specification (2) & Specification (3) \\
\hline Male & $\begin{array}{l}-0.152^{\mathrm{a}} \\
(0.036)\end{array}$ & $\begin{array}{l}-0.004 \\
(0.039)\end{array}$ & $\begin{array}{l}0.049 \\
(0.045)\end{array}$ \\
\hline Black & $\begin{array}{l}0.058^{\mathrm{a}} \\
(0.014)\end{array}$ & $\begin{array}{l}0.065^{\mathrm{a}} \\
(0.017)\end{array}$ & $\begin{array}{l}0.086^{\mathrm{a}} \\
(0.020)\end{array}$ \\
\hline Black male & $\begin{array}{l}0.030^{\mathrm{a}} \\
(0.010)\end{array}$ & $\begin{array}{l}0.046^{\mathrm{a}} \\
(0.012)\end{array}$ & $\begin{array}{l}0.063^{\mathrm{a}} \\
(0.015)\end{array}$ \\
\hline Black female & $\begin{array}{l}0.027^{a} \\
(0.010)\end{array}$ & $\begin{array}{l}0.018 \\
(0.012)\end{array}$ & $\begin{array}{l}0.023 \\
(0.014)\end{array}$ \\
\hline Hispanic & $\begin{array}{l}-0.022 \\
(0.037)\end{array}$ & $\begin{array}{l}-0.139^{a} \\
(0.038)\end{array}$ & $\begin{array}{l}-0.106^{\mathrm{b}} \\
(0.043)\end{array}$ \\
\hline Hispanic male & $\begin{array}{l}-0.070^{\mathrm{a}} \\
(0.026)\end{array}$ & $\begin{array}{l}-0.034 \\
(0.028)\end{array}$ & $\begin{array}{l}-0.007 \\
(0.033)\end{array}$ \\
\hline Hispanic female & $\begin{array}{l}0.048 \\
(0.033)\end{array}$ & $\begin{array}{l}-0.105^{\mathrm{a}} \\
(0.033)\end{array}$ & $\begin{array}{l}-0.099^{a} \\
(0.035)\end{array}$ \\
\hline
\end{tabular}

Standard errors are in parentheses. The coefficients in the table come from multivariate regressions of the outcomes on a dummy indicating whether the employer checks criminal backgrounds. The specifications are as follows. Specification (1) includes no control variables. Specification (2) includes 60 dummies for two-digit industry codes and dummies for the seven establishment size categories listed in Tables 5 through 7. Specification (3) adds a complete set of interaction terms between the 60 industry dummies and the 7 size dummies.

a. Parameter estimate statistically significant at the one percent level of confidence.

b. Parameter estimate statistically significant at the five percent level of confidence. 


\begin{tabular}{|c|c|c|c|}
\hline \multicolumn{4}{|c|}{$\begin{array}{l}\text { Table } 10 \\
\text { Instrumental Variables Estimates of the Impact of Employers Using Criminal Background } \\
\text { Checks on the Likelihood that the Most Recent Hire Into a Non-Professional, Non- } \\
\text { Managerial Job Is Male, Black, or Hispanic }\end{array}$} \\
\hline $\begin{array}{l}\text { Outcome } \\
\text { Variable }\end{array}$ & Specification (1) & Specification (2) & Specification (3) \\
\hline Male & $\begin{array}{l}-0.571^{\mathrm{a}} \\
(0.154)\end{array}$ & $\begin{array}{l}-0.017 \\
(0.229)\end{array}$ & $\begin{array}{l}0.266 \\
(0.243)\end{array}$ \\
\hline Black & $\begin{array}{l}0.217^{\mathrm{a}} \\
(0.033)\end{array}$ & $\begin{array}{l}0.376^{\mathrm{a}} \\
(0.121)\end{array}$ & $\begin{array}{l}0.457^{\mathrm{a}} \\
(0.151)\end{array}$ \\
\hline Black male & $\begin{array}{l}0.114^{\mathrm{a}} \\
(0.039)\end{array}$ & $\begin{array}{l}0.267^{\mathrm{a}} \\
(0.087)\end{array}$ & $\begin{array}{l}0.336^{\mathrm{a}} \\
(0.104)\end{array}$ \\
\hline Black female & $\begin{array}{l}0.103^{\mathrm{a}} \\
(0.039)\end{array}$ & $\begin{array}{l}0.109 \\
(0.073)\end{array}$ & $\begin{array}{l}0.121 \\
(0.081)\end{array}$ \\
\hline Hispanic & $\begin{array}{l}-0.078 \\
(0.139)\end{array}$ & $\begin{array}{l}-0.796^{\mathrm{a}} \\
(0.282)\end{array}$ & $\begin{array}{l}-0.556^{\mathrm{b}} \\
(0.264)\end{array}$ \\
\hline Hispanic male & $\begin{array}{l}-0.258^{\mathrm{a}} \\
(0.104)\end{array}$ & $\begin{array}{l}-0.190 \\
(0.172)\end{array}$ & $\begin{array}{l}-0.029 \\
(0.180)\end{array}$ \\
\hline Hispanic female & $\begin{array}{l}0.180 \\
(0.124)\end{array}$ & $\begin{array}{l}-0.607^{\mathrm{a}} \\
(0.225)\end{array}$ & $\begin{array}{l}-0.527^{\mathrm{a}} \\
(0.210)\end{array}$ \\
\hline $\begin{array}{l}\text { First stage } \\
\text { coefficient on } \\
\text { prohibition } \\
\text { against hiring } \\
\text { felons }\end{array}$ & $\begin{array}{l}0.266^{\mathrm{a}} \\
(0.033)\end{array}$ & $\begin{array}{l}0.173^{\mathrm{a}} \\
(0.035)\end{array}$ & $\begin{array}{l}0.188^{\mathrm{a}} \\
(0.038)\end{array}$ \\
\hline $\begin{array}{l}\text { F-Statistic, }{ }^{\mathrm{C}} \text { first- } \\
\text { stage (P-Value) }\end{array}$ & $\begin{array}{l}64.97 \\
(0.001)\end{array}$ & $\begin{array}{l}24.43 \\
(0.001)\end{array}$ & $\begin{array}{l}24.47 \\
(0.001)\end{array}$ \\
\hline
\end{tabular}

Standard errors are in parentheses. The coefficients in the table come from instrumental variables regressions of the outcomes on a dummy indicating whether the employer checks criminal backgrounds. A legal prohibition against hiring felons into the particular job is used as an instrument for checking. The specifications are as follows. Specification (1) includes no control variables. Specification (2) includes 60 dummies for two-digit industry codes and dummies for the seven establishment size categories listed in Tables 5 through 7. Specification (3) adds a complete set of interaction terms between the 60 industry dummies and the 7 size dummies.

a. Parameter estimate statistically significant at the one percent level of confidence.

b. Parameter estimate statistically significant at the five percent level of confidence.

c. Test-statistics from a test of the null hypothesis that the coefficient on the prohibition against hiring felons in the first stage equation is equal to zero. 


\begin{tabular}{|c|c|c|c|}
\hline $\begin{array}{l}\text { Table } 11 \\
\text { Comparison of Three-St }\end{array}$ & Ate Transition Probability & Matrix for 1 & \\
\hline Panel A: 1980 & & & \\
\hline & & Destinati & \\
\hline Origin State & $\begin{array}{l}\text { Not Incarcerated, not on } \\
\text { parole }\end{array}$ & Incarcerated & Parole \\
\hline $\begin{array}{l}\text { Not Incarcerated, not on } \\
\text { parole }\end{array}$ & 0.99937 & 0.00063 & 0 \\
\hline Incarcerated & 0.08211 & 0.52830 & 0.38958 \\
\hline Parole & 0.40390 & 0.13073 & 0.46538 \\
\hline Panel B: 2005 & & & \\
\hline & & Destinati & \\
\hline Origin State & $\begin{array}{l}\text { Not Incarcerated, not on } \\
\text { parole }\end{array}$ & Incarcerated & Parole \\
\hline $\begin{array}{l}\text { Not Incarcerated, not on } \\
\text { parole }\end{array}$ & 0.99826 & 0.00174 & 0 \\
\hline Incarcerated & 0.12697 & 0.50629 & 0.36674 \\
\hline Parole & 0.29738 & 0.29335 & 0.40927 \\
\hline
\end{tabular}

Author tabulations from National Prisoner Statistics data for various years. 


\begin{tabular}{|c|c|c|c|}
\hline \multicolumn{4}{|c|}{$\begin{array}{l}\text { Appendix Table A1 } \\
\text { Proportion of Establishments Legally Prohibited from Hiring a Convicted Felon Into the } \\
\text { Last Filled Non-Managerial, Non-Professional Job by Two-Digit Standard Industrial } \\
\text { Classification Codes }\end{array}$} \\
\hline Industry & $\begin{array}{l}\text { Proportion } \\
\text { prohibited }\end{array}$ & $\begin{array}{l}\text { Standard } \\
\text { error }\end{array}$ & $\mathrm{N}$ \\
\hline General Building Contractors & 0.148 & 0.095 & 15 \\
\hline Heavy Construction Contractors & 0.000 & 0.000 & 4 \\
\hline Special Trade Contractors & 0.190 & 0.073 & 30 \\
\hline Food \& Kindred Products & 0.028 & 0.040 & 18 \\
\hline Textile Mill Products & 0.000 & 0.000 & 3 \\
\hline Apparel \& Related Products & 0.000 & 0.000 & 5 \\
\hline Lumber \& Wood Products & 0.000 & 0.000 & 7 \\
\hline Furniture \& Fixtures & 0.000 & 0.000 & 6 \\
\hline Paper, Allied Products & 0.382 & 0.217 & 6 \\
\hline Printing \& Publishing & 0.032 & 0.051 & 13 \\
\hline Chemicals, Allied Products & 0.174 & 0.114 & 12 \\
\hline Petroleum Refining \& Related Industries & 0.416 & 0.285 & 4 \\
\hline Rubber \& Plastics & 0.000 & 0.000 & 4 \\
\hline Leather \& Leather Products & 0.000 & 0.00 & 1 \\
\hline Stone, Clay \& Glass Products & 0.000 & 0.000 & 8 \\
\hline Primary Metal Industries & 0.000 & 0.000 & 8 \\
\hline Fabricated Metal Products & 0.034 & 0.061 & 10 \\
\hline Machinery Except Electrical & 0.060 & 0.052 & 22 \\
\hline Electrical Equipment & 0.055 & 0.038 & 36 \\
\hline Transportation Equipment & 0.308 & 0.109 & 19 \\
\hline Instrument-Related Products & 0.239 & 0.114 & 15 \\
\hline Miscellaneous Manufacturing & 0.123 & 0.134 & 7 \\
\hline Railroad Transportation & 0.000 & 0.000 & 3 \\
\hline Local Passenger Transportation & 0.487 & 0.204 & 7 \\
\hline Trucking \& Warehousing & 0.163 & 0.095 & 16 \\
\hline Transportation by Air & 0.295 & 0.456 & 2 \\
\hline Transportation Services & 0.067 & 0.251 & 2 \\
\hline Communication & 0.365 & 0.139 & 13 \\
\hline Electric, Gas, Sanitary Services & 0.000 & 0.000 & 6 \\
\hline Wholesale Trade & 0.051 & 0.037 & 36 \\
\hline Wholesale Trade Nondurable Goods & 0.121 & 0.062 & 29 \\
\hline Bldg Materials, Hardware \& Garden Suppl & 0.154 & 0.147 & 7 \\
\hline General Merchandise & 0.137 & 0.069 & 26 \\
\hline Food Stores & 0.000 & 0.000 & 17 \\
\hline Auto Dealers \& Service Stations & 0.087 & 0.075 & 15 \\
\hline Apparel Accessories Stores & 0.000 & 0.000 & 8 \\
\hline Furniture \& Home Furnishings & 0.132 & 0.169 & 5 \\
\hline Eating \& Drinking Places & 0.084 & 0.034 & 67 \\
\hline Miscellaneous Retail Stores & 0.147 & 0.091 & 16 \\
\hline Banking & 0.353 & 0.123 & 16 \\
\hline Credit Agencies, Except Banks & 0.226 & 0.132 & 11 \\
\hline Securities, Commodity Brokers, Services & 0.595 & 0.174 & 9 \\
\hline
\end{tabular}




\begin{tabular}{lrrr} 
Insurance Carriers & 0.645 & 0.144 & 12 \\
Insurance Agents, Brokers, \& Services & 0.214 & 0.130 & 11 \\
Real Estate & 0.205 & 0.090 & 21 \\
Holdings, Real Estate, \& Investment Cos & 0.000 & 0.000 & 2 \\
Hotels, Recreation Lodging Places & 0.168 & 0.071 & 29 \\
Personal Services & 0.303 & 0.188 & 7 \\
Miscellaneous Business Services & 0.207 & 0.046 & 77 \\
Auto Repair, Services \& Garages & 0.039 & 0.052 & 15 \\
Miscellaneous Repair Service & 0.000 & 0.000 & 6 \\
Motion Pictures & 0.069 & 0.090 & 9 \\
Amusement Recreation Services & 0.253 & 0.105 & 18 \\
Health Services & 0.359 & 0.044 & 118 \\
Legal Services & 0.124 & 0.147 & 6 \\
Social Services & 0.895 & 0.065 & 23 \\
Museums, Botanical Gardens, Zoos \& Gard & 0.285 & 0.226 & 5 \\
Membership Organizations & 0.093 & 0.075 & 16 \\
Engineering \& Management Services & 0.475 & 0.078 & 42 \\
\hline
\end{tabular}

